\title{
Suça iştirak
}

\section{Yazan: Doçent Dr. Faruk Erem}

\section{BÍRINCI BÖLÜM:}

I. Giriş: A. Sistemier; B. Suça iştirakin müstakil hâdise olarak incelenmesi; II. Isstirakin genel şartları: A. Manevi unsur: (a. kastin mahiyeti; b. Hata; c. Anlaşma anı; ç. Taksirli suçlar; d. kabahatler); B. Maddì unsur: (a. Katılma; b. selbî fiiller; c. İştirake teşebbüs; ç. Teșebbuise iştirak; d. Tamamlanmamış suç.

III. Muhtelif suçlar bakımından iştirak: A. Toplu suçlar; B. mütemadî, müteselsil suçlar $C$. Muayyen sıfatı haiz kimselerin sưçları; Ç. İşliyeni bilinmiyen adam öldürme ve müessir fiil; D. Kavga.

\section{İKiNCİ BöLỪM:}

İştirakin nevileri: I. Astî iştirak; A. Aslî maddî iştirak: (Suçu irtikâp edenler; Dơ̆grudan dơ̆ruya beraber işliyen. ler) B. Manevî - aslî iştirak: (a. azmettirmede manevî unsur; b. Azmettirmede maddî cnsur; c. Azmettirme vasıtaları; ç. Azmettirme şekilleri; 1. suçta vekâlet; 2. Teşci; 3. Birlik; d. Azmettirmenin cezası, şahsî menfaatten ileri gelen tahfif sebebi); II. Fer'î iştirak: A. Fer'î - maddî iştirak: (a. Vasıta veya is tedariki; b. mìzzaheret, muavenet); B. Fer'î - manevî iștirak: (a. Teşvik; b. Karan takviye; c. Müzaheret. muavenet vadi; ç. Talimat vermek); C. Fer'î iştirakte zaruret: (a. Zarưî olmıyan ferî̀ iştirak; b. Zarưî̀ olan fer'î iştirak).

\section{ÜÇƯNCỪ BöLÜM:}

Cezaya müessir sebeplerin ortaklara sirayeti: I. Cezayı kaldıran sebepler; II. Cezayı arttıran sebepler: A. Cezayı arttıran kişiye bağlı sebepler; B. Cezayı arttıran fiilî̀ sebepler.

\section{B İ R I N C I B ö L Ù M}

I. GIRIŞ: Bir suçun birden ziyade kimseler tarafından işlenmesi mümkündür. Aynı suçta birden fazla failin bulunması, onları suçta ortak haline sokar. Ortakların birlikte işlemiş oldukları suça nazaran mesuliyetlerinin tâyini için hususî̀ kaidelere ihtiyaç vardır. 
"Suça iştirak" hükümleri (CK. m. 64 - 67) bu ihtiyacı karşlamak için konulmuştur (1).

A. SIST'EMLER: Iştirakte ortakların mesuliyetini tâyin hususunda üç sistem düşünülebilir: (2)

Birinci sistem, cezada ve mesuliyette müsavat sistemidir. Bu sisteme göre başkasının fiiline iştirak eden kimse, onun fililini bütün neticeleri ile kendine maletmiş sayılmalıdır. Suça ortaklıktaki hisseleri ne olursa olsun bütün ortaklar aynı cezaya çarpılmalıdır. Roma hukukunda prensip olarak kabul edilmiş olan bu sistem, 1791 ve 1810 Fransız ceza kanunlarına da intikal etmiştir (3).

İkinci sistem, ceza hukukunda klâsik mektebin isteklerine en fazla uyabilen sistemdir. Bu sisteme göre ortakların mesuliyetini suçun işlenmesindeki faaliyet hisselerine göre tâyin etmek lâzımdır. Bu sebeple ortaklarm aslî ve fer'î olarak tefrik edilmesi ve aslî faillere verilecek cezanın fer'î faillerin cezasından üstün olması icap eder. Çünkü suçun müessir sebebi aslî faillerdir, fer'̂̂ failler ise sadece yardimcidirlar.

Türk Ceza kanununca kabul edilen hükümler ikinci sisteme uygundụr. Kanunumuza göre aslî faillerle (m. ü4) fer'î failler (m. 65) in mesuliyeti farklı cezalarla müeyyidelendirilmiştir.

Ưçüncü sistem, ortaklarm ceza mesuliyetlerini biribirinden ayıran ve iştirakte maddî veya manevî alâka nisbetlerine göre değil, kötülük derecelerine göre ceza verilmesini isteyen sistemdir. Yeni

(1) BIBLiYOGRAFi: ALTAVÍlla, Delitti contro la persona, Milano 1921. - BECCARIA, Des délits et des peines, Paris 1856. - BRUNO, Codice penale del regne d'ítalia, 1927. - CASABtANCA, Code pénal du royaume d' Italie. - DALLOZ, Code d'instructien criminelle et code pénal, Paris 1922. - FERRI, Sociologie criminelle. - FLORIAN, Parte generale del diritto penale, C. II, bası 3, Milano 1926. - GARÇON, «rapor" Congrès pènitentiaire international de Washington (ayri bas1) 1910. - GARAFALO, Criminologie, bas1 5, Paris 1905. - GARRAUD, Drait pénal frangais, C. II, bas1 3. Paris 1915. - KANTAR, Ceza hukuku. - LOGOZ, Commentaire du code Pénal suisse, Nöşatel, 1939. - MANZINI, Trattato di diritto penale italiano, C. II, basi 2, Torino 1926. - MAJNO, Ceza kanunu serhi, atercümen, C. I, Ankara 1927. - Nocito, Enciclopedia del diritto penale italiano, C. V. s. 307 386. - POZzolíni, istituzioni di diritto penale italiano 1921. - Pessina, II nuovo cedice penale italiane, Milano 1890 . - PRINSS, Science pénale et droit pesitif, Brüksel, 1899. - ROSSi, Traité de droit pénal, Paris 1872. SUMAN, II codice pénale italiano, Torino 1892. - TANER, Ceza hukuku. VIDAL, Cours de droit criminel, basi 8, Paris 1935.

(2) Vidal đörtlü bir tasnif kabul eder, n. 406.

(3) Vidal n. 406. 
İsviçre ceza kanunu (m. 24 - 26) mutedil bir şekilde, Yeni İtalyan Ceza kanunu (m. 110) tamamile ortaklarm mesuliyette ayrı tutulmaları fikrinden mülhem olmuştur (4).

B. SUÇA İSTIRAKİN MƯSTAKIL HÂDISE OLARAK TETKİKİ: Bir suçun ortakları arasındaki münasebeti tâyin hususundaki hükümlerden müstakil olarak "işstirak" müstakil bir hâdise olarak da tetkik edilebilir. Meselenin böyle bir cepheden yaplan ilk incelemesini pozitivistlere borçluyuz.

Ferri'ye göre (5) bir ihtiras dalgası içinde bir cürüm işlemiş olan topluluk hali müstesna en az tehlikeli suçlular (tesadüfî suçlar, ihtiras suçlưları) suçu yalnız ve ortaksız işlemek hususunda devamhl bir psikolojik karakter arzederler. Halbuki en tehlikeli olan suçlularda (doğuştan suçlular, itiyadî suçlular) aksi müşahede edilir. $O$ halde bu sonuncular için iştirak hali, müstakil bir cezayı arttırı̣cı sebep sayılmalıdır.

Garrafolo'da, Ferrî gibi düşünmektedir. Garrafolo'ya göre (3) ortakların aynı sunıfa mensup suçlular olmadikları halde aynı mahiyetteki cezalara çarpılmaları anlaşılmaz bir şeydir. Bir kimse ailesinin uğramış olduğu kanlı bir taarruzun intikamını almak için diğer bir kimseyi bu intikamı alması için para ile tutsa, intikam saiki ile hareket eden kimse ile para ile tutulmuş olan şahıs birbirinden farklı kimseler değil midir? O halde neden aynı mahiyetteki cezalara çarpılsınlar? Neden hırsızhı̆̆ meslek edinmiş kimse ile bu kimse tarafindan hırsızlığa sürüklenmiş diğer bir şahıs aynı cezayı görsün?

Ferri'nin düşüncelerini genişleten ve pozitivistlere göre umumî iştirak nazariyesini etraflıca tetkik eden Sighele (7) de ayn neticeye varmış ve tasarlanmış iştirakin (complicita premeditato) yalnuz suç için cemiyet teşkili ve saire gibi muayyen hallerde değil, umumî bir şiddet sebebi sayılması lâzım geleceği neticesine varmıştır. Çünkü iştirak bilhassa ağır suçlarda görülen bir haldir ve iştirak hâdisesi çok kötü ruhlu suçlularm bilhassa hırsızların katillerin kullandıkları bir şekildir. İştirak halinde suç işleyenler doğuştan suçlu, itiyadî suçlulardir.

Positivistler tarafından ileri sürülen bu düşüncelerin doğrulu-

(4) Bu hususta Vidal, n. 406; Logoz s. 92; Casabianca m. 110 not.

(5) Ferri s. 478.

(6) Garrafalo, s. 352 - 353.

(7) Sighele, La teorica positiva della complicita, Ferri'den naklen, s. 479 not 1; Sighele nazariyesi hakkında Florian s. 15, 16; Garçon «rapor, aytı bas1» s. 3. 
ğundan şüphe edilemez. İstatistikler iştirak halinde suç işlemenin mahiyetleri en ağır olan suçlarda ekseriyeti teşkil ettiğini göstermektedir (8). O halde ekseriya yığın içinde suç işlemek halinde tesadüf edilen âni iştirak hâdiseleri hariç olmak üzere, tasarlanmış iştirak hallerinin cezayı arttımcı umumi bir sebep olarak kabulü doğrudur. Pozitivist mektebin düşünceleri ile bir dereceye kadar klâsik mektebin đüşüncelerini bu sahada telih imkânı bulabilir. Hem ortaklarm suç husulündeki hisselerini nazarı itibare almak ve hem de iştiraki müstakil bir şiddet sebebi saymak mümkündür (9). Çünkü birden ziyade kimselerin birleşmesinden bunların ferden sahip olmadıkları maddî ve manevî kuvvetler ortaya çıar, artan tehlikeye karşı şiddetli ceza vazetmek makul bir düşüncedir (10).

Türk Ceza kanununda fiilin müstelzim olduğu ceza ölçü tutulmakta, ve aslî faillere verilecek ceza ile aynı suçun bir kişi tarafından işlenmesi halinde verilecek ceza arasında fark görülmemekte ve fer'î faillerin cezası da indirilmektedir. $O$ halde kanunumuz iştirakin umumî bir șiddet sebebi olmasını kabul etmemektedir. Buna mukabil, bazı suçlar hakkında kanun suçta birden ziyade kimselerin birleşmesini hususî şiddet sebebi olarak kabul etmek suretiyle (11) bu ihtiyacı hissetmiş ve bu ihtiyacı bir dereceye kadar gidermek için de hususî hükümler vazetmiştir, denilebilir.

(8) Pozzalini s. 172.

(9) Bu hususta Pozzolini s. 172.

(10) İştirakin unumî şiddet sebebi sayılması tanınmış birçok müelliflerce kabul edilmiştir. Garraud ${ }^{2}$ C. III, n. 883* bu sebeplerin iştirakin müstakil bir suç sayılmasını bile haklı gösterebileceğine kanidir; Pozzolini «s. 172» iştirakin şiddet sebebi saylmasina taraftar, müstakil sự sayılmasına muhaliftir; Manzini \&n. 493* birlesme keyfiyetinde fiil ve kastta bir kesafet ve cemiyet için de tehlikeli bir durumun mevcut olduğunu, kabahatler hariç suç işlemek için birleşmelerin şiddetli cezalandırılmasınin cemiyet menfaatine vè adalete uygunluğunu ve en iyi çarenin hâkime, bütün suçlara kabili tatbik ve ortakların sıfatına bakılmaksızın cezayı arttırma imkânı veren bìr hïkmün kanuna konulması olduğunu bildirmektedir; Gatçon „ «rapor, ayrı bası s. 13» iştirak halinin müstakil suç sayılmasına muhalif, suç için cemiyet teşkilinin müstakil sụ sayılması ile bu htiyacın tatmininin mümkün olduğgu, iştirakin umumî bir şiddet sebebi sayılmasının da aşılmaz mânilerle karşılaşacağını, ezcümle ancak birkaç kişi tarafindan işlenebilecek suçlara böyle bir şiddet sebebinin tatbiki inkânsız oldựunu. taksirli adam ölduirmede birçen zìyade ortak bulunmasınin cezayı artturan bir hal olarak kabul edilemiyeceğini bildirmektedir.

(11) Bk. m. 168, 171, 188, 183, 236, 254, 299, 417, 497, 514, 517; bu hususta Pozzolini n. 172; Manzini n. IV.

Hukuk Fa'zültesi Mecmuası 5 
II. İŞTIRAKİN GENEL ŞARTLARI: Türk Ceza Kanunu ortaklarm aslî veya fer'î şekilde suça iştirak edebileceklerini kabul etmekte iki iştirak nev'ine ait hükümleri ayr maddeler halinde göstermektedir. Bununla beraber her iki iştirak halinin vücudü için bulunması gereken umumî şartlar aynıdır:

A. MANEVÎ UNSURLAR: Suç ortaklarının muayyen bir suçun işlenmesine iş̧tirak ettiklerini bilmiş ve bunu istemiş. olmaları làzımdır, yani her failde suça iştirak kasdi bulunmalıdır. Kastin bulunması yolundaki şartın iş̧irak hükümlerinde särahaten zikredilmemis olması, böyle bir sarahate lüzum görülmediğindendir (12), çünkü 45 inci madde hükmü iştirak hakkında da caridir. İştirak hükümlerinde böyle bir kaydın mevcut olmaması sebebi sadece lüzumsuz tekrarlara mlydan vermemek içindir.

a) KASTIN MAHİYETI: İştirakin manevî unsuru «suça iştirak iradesi” dir. Bundan gayrı bir irade, kanunun sarahati bulunan hallerde $(169,314$ üncü maddelerde olduğu gibi) müstakil bir suç unsuru olabilirse de, iştirakin manevî unsuru olamaz (13).

İştirak iradelerinin muayyen bir suç üzerinde birleşmesi anlaşmayı meydana getirir. İki aslî failden biri öldürmek, diğeri sadece müessir fiide bulunmak iradesi ile hareket ederlerse, husule gelen suçta ortak sayılmazlar, ortada iki ayrı suçun müstakil failleri vardır (14). Kastı aşan suçlarda (452, 458 inci maddelerde olduğu gibi) ise iștirak hali mümküindür, çünkü suçu teşkil eden fiilin muhtevaS1 bakımından ortaklar arasında bir anlaşmazlık mevcut değildir (15).

Bir suça iştirak etmiş olduğunu bilmeyen bir kimsenin bu bilmemezliği iş̧irakin maddî unsuru hakkında fijlde bilmemezlik (fiili cihalet) haline sebebiyet verir ve bilmemezlik hakkındaki umumî nazariye gereğince kastı da ortadan kaldırır. Bir adam öldürmek için kullanacağını bilmeksizin bir şahsa silâh tedarik eden silâḩ̧̧,

(12) Meyhaz kanun hazırlanırken hükümlerine «Scientemente» yahut conoscendone ile fine criminoson kayıtlarının ilâvesi ileti sürülmüș ve bu fikir projenin gözden geçirilmesi için kurulan komisyonda Pessina tarafindan müdafaa edilmis olmasına rağmen Lucchini'nin eğer böyle bir sarahat kabul edilecek olursa bütün ceza kanunu sisteminin yıkılacağı, çünkii bu sistemin esasının bütün suçlaxda zaten suça vukuf şartını aradı̆̆ını bildirmesi üzerine kabù edilmemiştir. Bu hususta Florian s. 46; Majno m. 63; no. 322; Pozzolini n. 174.

(13) Manzini n. 484.

(14) Manzini n. 477.

(15) Manzini n. 488 IV. 
bir iş̧̧i ile konuşurken evin dahilî taksimatı hakkında hursızlıkta istifade edileceğini bilmeksizin malûmat veren kapıcı (16) suça iştira ketmiş sayilmaz (17).

b) HATÂ: Bilmeden suça iştirak ile hata neticesinde işlenilmiş suça iştirak halleri birbirinden farkhıdır. Hata neticesinde işlenilmịs suçta, netice iradi olmadığından böyle bir suç hakkında iradelerin birleşmesi halinden bahsedilemez. Hata neticesinde işienmiş suçlarda ceza kanununun aradığ şartlara uygun bir kusur mevcut ise taksirli suçtan dolayı ve her fail kendi fiilinden mesul tutulur (18). Kendisine malsahibi süsü veren bir hırsız bir çilingire evin kilidini açtırır ve hırsızlık suçunt da işlerse, çilingirin ihtiyatsızca hareketi hırsızlığa iştirak değil, niüstakil bir suçtur (m. 583).

Ortakların sarih bir anlaşmaya varmış olmalarına rağmen, fiilin ikal sirasinda hataya düşmeleri halinde, hâdiseyi bir tahlile tâbi tutmak lâzımdır: Adam öldürme suçunu irtikâp etmek veya doğrudan doğruya beraber işlemek (maddî aslî iştirak halleri) üzere anlaşan aslî failler yanılarak öldürmeyi istedikleri kimseden başkasını öldürecek olurlarsa, zannımıza göre, iştirak hali teşekkül etmiştir. Başkası tarafından suç işlemeğe azmettirilmiş olan kimsenin hataya düşerek azmettirenin istediği kimseden başka bir kimseyi öldürmesi halinde de iştirak hali husule gelmiş sayılmalıdır, çünkü azmettirilmiş kimsenin hatası, anlaşma hududunu aşan bir netice doğurmuş sayllamaz. Bu her iki misalde de muayyen bir suçu işlemek hususunda anlaşma mevcuttur ve netice anlaşma hududu içinde kalmıştır, çünkü adam öldürme suçunda muayyen bir kimsenin değil herhangi bir kimsenin öldürülmüş olması kâfidir, bu gibi hallerde 52 inci madde hükmü mahfuzdur.

c) ANLAŞMA ANI: Muayyen suç üzerinde iradelerin birleşmesinden ibaret olan anlaşmanın suçun tekemmülüinden evvelki safhada yer almış olması lâzımdır. Suçun tekemmülünden sonraki anlaşmalar müstakil suçların unsuru olabilir. Ańlaşma anının sạih olarak bilinmesi ne zaman hususî suç hükümlerinin ve ne zaman da iştirak hükümlerinin tatbiki lâzım geleceğini tâyin eder:

Çalacağı malı satacağını veya imal edeceği kalp parayı süreceğini suçluya, suçtan evvel vadeden kimse, Adliye aleyhine ișlenilmiș

(16) Prins ก. 549.

(17) Aynu mahiyette Majno n. 345.

(18) Aynı mahiyette Majno n. 323. 
bir suç olan 296 mcu maddedeki suçu irtikâp etmiş olmaz. Suçtan evvel yapilan bu nevi anlaşmalar neticesinde işlenen fiiller iştirak mefhumuna dahildir. Hattâ iştirakin kabulü için vadin ifa edilmî̧ olmasına da ihtiyaç yoktur, çünkü yerine getirilmemiş olsa bile, vait suç iradesini kuvvetlendirmiş olmakla vadedenin iştirakteki mesuliyet hissesini tâyin etmiştir.

Suçtan sonra adliyenin faaliyetini şaşırtmak hususunda suçtan evvel yaplan anlaşma sonunda vait de ifa edilmiş ise, ortada cezayı gerektiren iki halin bulunduğu, bunlardan birisinin muzaheret vadi ile suça manevî bir iştirak diğeri de adliye aleyhine işlenmiş 296 incI maddedeki suçtan ibaret bulunduğu ve bu gibi hatlerde tek fiil ile birden ziyade hüküm ihlâl edildiğine göre 78 inci maddeye göre karar verilmesi lâzım geldiği mütalâası da ileri sürülmüşür (19).

Anlaşma anının tâyininde "suçu tekemmülünden evvel anlaşma" kıstasının kabulü yerinde olur. Çünkü suçtan evvel anlaşma ile suçtan sonra anlaşma arasında mutavassıt bir safha meveut olabilir: suę aninda anlaşma.

Bu mutavassit safhadaki anlaşmıya beklenilmeyen suçlar (delitti improvissi) da tesadüf olunur. Ani bir kızgınlık, coşma neticesinde birkaç kişinin birlikte harekete geçmeleri hâdiselerinde kenidni gösteern bu nevi suçlar da iştirakin mevcut olup olmryacağı hususu münakaşalıdır. Böyle bir ruhî durumda bulunan kimselerin iştirakin 'şartı olan anlaşmıya varmış olmalarmın kabulïne imkân olmaması mutaleasina istinat eden bazı müellifler bu nevi suç̧ar için iştiraki kabul etmemekte ve her failin kendi fillinden, diğerlerinden müstakil olarak mesul olması lâzım geldiğini ileri sürmektedirler. Fakat ekseriyeti teşkil eden müellifler aksi fikirdedir, bu müelliflere göre: iştirakte şart olan ortaklarnn evvelce anlaşmış olmaları değildir, ortaklar arasında bir anlaşmanın mevcut olması kâfidir, ortaklar arasınd ani bir anlaşma sadece mümkün değil, aynı zamanda ekseriyetle tesadüf edilen bir haldir, yeter ki onu icap ettirecek firsat zuhur etsin (20). Bu gibi hallerde anlaşmanın meveut olup olmadığının tâyini "hukukî bir mesele olmaktan ziyade takdirî bir meseledir» (21).

O halde beklenilmiyen suçlarda anlaşmanın bilhassa iştirakin mevcut olmadığını, evvelden tâyine imkân yoktur, hâdisenin hususiyetlerine ve hal ve şartlara göre bir neticeye varmak lâzım gelir.

(19) Nocito s. $352,353$.

(20) Bu hususta Manzini n. 476, 488; Pozzolini n. 174.

(21) Majno n. 323. 
Nasil bu gibi suçlarda anlaşmanin hiçbir zaman mevcut olamıyacağı iddia edilemezse, aynı anda iki kişinin aynı suçu işlemesi hallerinde de her zaman bir anlaşmanm meveut olduğu da ileri sürülemez (22).

ç) TAKSIRLİ SUÇLAR: Taksirli suçlarda iştirakin kabul edilip edilemiyeceği ihtilâflı bir meseledir.

Bazı müelliflere göre iştirakin unsuru olan "anlaşma" ile taksir mefhumunun telifine imkân yoktur, anlaşma kasța dayanır, taksir ise kastın bulunmadiğ hallerde aranılan bir kusurdur (23).

Diğer bazı müellifler taksirli suçlarda, iştirakin mümkün olacağı fikrindedirler. Bu müelliflere göre taksirli filler dahi iradeye dayanan fiillerdir. Taksirde fiil irade edilmiş ve ancak netice istenmemiştir. Bu sebeple fiilin işlenmesi hususunda failler arasında bir irade birleşmesi daima mümkündür. Meselâ " $\mathrm{X}$ " odun keser, "Y" bunIarı toplar, "Z) bu odunları tehlikeli bir yerde yakacak olur ve bundan bir yangın husule gelirse bu ü̧̧ şahıs taksirli bir suçun hem fiilleridir, çünkü hepsinin müşterek gayeleri birlikte isınmaktır ve taksirli suç bunların birleşmiş kuvvetlerinden ileri gelmiştir. Aynı istikamette frensiz iki arabanm çok büyük bir sür'atle gitmesi esnașında ikisi arasinda kalarak bir kimsenin ezilmesi halinde de araba sürücüleri hem fiildirler (24).

Taksirli suçlarda iradelerin birleşemiyeceği iddiası nazarî bir iddiadır, iradelerin fiilen birleştiği her hâdisede iştirak mevcut olabilir. Kalabalık bir yolda nizamata muhalif olarak bisikletle yarış edenlerin ve kalabalık bir mahalde atış talimi yapanlamn fiillerinde olduğu gibi (25) diğer birçok hâdiselerde de iradeler arasında fiilî bir birleşme daima mümkündür.

Taksirli suçlarda iştiraki kabul eden müelliflerin fikri daha yerindedir. Halen nakil vasitalarının tekemmülü ve bunların işletmelerinde görülen komplike durum, birçok taksirli suçlarda failleri

(22) Garraud «s. 574» şu misali verir: «bu ipoteze nadiren tesadüf edilir, fakat mümkündür. Meselâ iki kimse öldürmek istedikleri bir şahsın yolunu bekierler, iki silâhtan aynı zamanđa iki kurşun çıkar, mağdưr biri başından, digeri kalbinden olmak üzere iki yara alırsa, her iki suçlunun durumu ayri ayrıdır, bir mağdur olmașına rağmen ortada iki suç vardır».

(23) Ittalyan Yargıtay kararı; Bruno m. 63! «taksirli suçlanda hem fiillik ve fer'an zimethallik kabul edilemez. Zararlı neticeyi doguran sebepler ayrı ayrıđır, her suçlu kendi kusurundan mesuldïr».

(24) Misallet Manzini'den alınmıștır, n. 488 II.

(25) Altavilla, n. 145. 
müstakil olarak tâyine imkân bırakmamaktadir, bir demiryolu istasyonunun işletmesi düşünülecek olursa bu düşüncelerin doğruluğu daha fazla anlaşılır.

Taksirli suçlarda iştiraki kabul için.suçu husule getiren fiilden iradelerin birleşmesi lâzımdır, hâdisede mevcut müstakil ve müteaddit taksir sebeplerinin sadece bir araya gelmesi kâfi değildir. Meselâ bir istasyon şefi, aksi istikametten gelen bir katar makinistine haber vermez ve makinist te nizamlara göre lüzumlu olan emniyet hareketlerine tevessül etmezse, kaza vukuunda istasyon şefi ile makinist hem fiil sayllamazlar (26).

Taksirli suçlarda iştirakin kabul edilip edilmemesi, hem fiilter bahis mevzuu olduğu zaman tamamile nazarî bir münakaşa halinde kalmaktadır, çünkü hem fiiller müstakil telâkki edilse bile, her biri kendi taksirinden mes'ul tutulacaklarından cezasız kalmiyacaklardır. Şiddet sebeplerinin sirayeti bakımından bu iki görüşün başka başka neticeler vereceği endişesi de sirayet için şart olan "vukuf» unsuru ile bertaraf edilmektedir.

Taksirli. suçlarda fer'î iştirake gelince kanunun metnine göre. bu nevi iştiraki kabule imkân yoktur, çünkü fer'î işstirakin kanun tarafından tâyin edilmiş olan bütün şekilleri iştirak fiilini ve neticeyi isteyen faaliyetlere ihtiyaç göstermektedir, bu ise taksirle uzlaşması imkânsız bir haldir.

Taksirli bir suçta aslî bir iştirakin kabulü doğru ise de, böyle bir suç iradî bir iştirak veya kasdî bir suça taksirli bir iştirak huktukan kabili tasavvur değildir, böyle hallerde herkes kendi fiilinden ve şartları mevcut ise taksirli veya kastî suçundan mes'ul olưr (27, 28).

d) KABAHATLER: Kabahatlerde iştirak mümkündür. Kanun sarahaten bu hususu işaret etmektedir (29). Kabahatlerde manevî unsurdan bahseden 45 inci maddenin son fikrası ile kabahatlerde iştiraki sarahaten kabul eden iştirak hükümleri arasında tenakuz yoktur. Çünkü 45 inci madde kabahatlerin kastsiz suẹlar olduğunu de-

(26) Manzini n. 488.

(27) Manzini 488.

(28) Aksine karar, İtalyan yargitayı, Bruno m. 63: «Bir adam öldürme suçunu irtikâp edeni öldürmek kasți ile fiili işlemiş kabul eden ve doğrudan dŏğruya beraber işlemiş olanı da bukasta sahip olmaksızın fiili işlemiş sayan hüküm mütenakız bir hüküm değildir».

(29) Bk. Altıncı bap, başlık. 
ğil, bilâkis bunların da cürümler de olduğu gibi kasta dayanan fiillerden bulunduğunu ve aradaki farkın sadece isbat külfeti meselesini ilgilendirdiğini ifade etmektedir.

B. MADDÎ UNSUR: İștirak halinde suç, birden ziyade kimselerin fiillerinin birleşmesinden husule gelir. $O$ halde sebepler müteaddit, suç tektir. İştirak halinde işlenilmiş suçun böylece bir bütün teşkil ettiği görülür.

a) KATILMA: İştirakin maddî unsuru, bütüne müessir şekilde katılmakỉa husule gelir. Suçun husule gelmesinde tesirli bir faaliyet de bulunmuş olması ortağın mesuliyetinde maddî unsuru teşkil eder. Bu sebeple suç ortağının mesuliyetinin esası başkasının işlemiş olduğu bir fiil değil, kendisinin suç teşkil eden bir fiile sebep oluşundandır. Çünkü tek olan suçun müteaddit sebepleri arasında ortağın da faaliyeti yer almaktadir.

Sadece anlaşmanin mevcut olmasi, ortaklarm mesul tutulmaları için kâfi değildir. İştirakin maddî unsurunun da vücudü lâzımdır.

Sözleşmenin husule gelmiș olmasına rağmẹn iștiraki tazammun eden fiiller işlenmemiş ise ortaklık yoktur.

Maddî fiillerin işlenmesine rağmen bunların neticesiz sayıldığı hallerde de iştirak cezayı mucip değildir. Bu sebeple bir başkasını işlenmez suça (muhal suç) azmettiren - işlenmez suçta mesuliyeti kabul etmiyen telâkkiye göre - cezalandırılamaz. Suç olmaktan çkmış bir fiile iştirakten dolayı da ortakların cezalandırılması imkânsızdır (30).

Intihar etmek suç değildir, bu sebeple başkasımın intihar fiiline iştirakin de cezalandırılmaması lâzım gèleceğini düşünmüş olan kanun bu hususun sarih bir hükümle müstakil suç saymıştır (m. 453) $(31,32)$.

Aile hrrsızhğı (m. 524) sadece bir cezasızlık sebebidir. Cezasızluktan istifade eden yalnız bu sebep kendinde bulunandır, suç baki

(30) Aynı mütalâa Pozzoloni, n. 178.

(31) Bu maddede intihara, ikna ve buna yardimdan bahsedilmektedir. Meyhaz kanunun bu maddeye tekabuil eden 370 inci maddesinde «başkasin intihara azmettirmek veya intiharda muvayenet etmek» kaydt mevcuttur. Kanunumuzun 64 üncü maddesinde xazmettirmeks 453 üncü anddesinde ise «ikna etmek» denilmesine müsteniden lâfzı bir tefsire temayül etmemek ve iknaya, azmettirme mânasından gayrı bir mâna atfetmernek muvafik olur.

(32) Intihara azmettirmek, muavenet etmek meseleleri hakkinda Altavilla n. 224; Pozzolini n. 178. 
kaldığından iştirak mümkündïr. Buna mukabil meşru müdafaa şartlarından istifade edenin fuiline iştirak cezalandırılamaz, çünkü iştirak filinin merbut olduğu aslî fiil suç değildir (33).

b) SELBİ FiliLLER: Kanunun iştirak hakkmdaki hükümleri münahasiran icabî fiillere yer vermiş gibiđir. $\mathrm{Bu}$ sebeple selbî bir iştirakin kabul edilip edilemiyeceği meselesi ortaya çıkar. Suç mahallinde hiçbir icraî fiil işlemeksizin sadece hazır bulunmak, yahut, bakmak, nezaret etmek, korumak gibi vazifelerle mükellef olanlarmn sadece hareketsiz kalmak suretile suçun işlenmesine imkân vermeleri gibi hâdiselerde bu selbî hareketlerin iştirakin maddî unsurunu teşkil edip etmiyeceğini tâyin etmek lâzımdır. Şüphesiz iştirakin sadece menfî șekli (forma di concorso negativa) kabul edilemez, bir suçun işlenmesine mâni olmamak 'suç sayılmaz $(34,35)$, fakat selbî fiillerle (evin arkadaşları tarafindan soyulabilmesi için kapıyı kapamıyan hizmetçinin fiili gibi) husule gelecek bir iştiraki kabul etmeme kiçin sebep yoktur (36), iradi olan bir hareketsizlik suçun husulünde tesirli bir unsur olabilir, kanunun iştirals hakkındaki hükümlerinde munhasıran icabî fiillere yer vermiş olduğu düșüncesi varit değildir, çünkü icabî fiillerden mütevellit neticelerin selbi fiillerde de elde edilmesi daima mümküdür (37). Hukukî bir vazifenin ifa edilmemiş olması halinde iştirak mevcıttur (38). Diğer taraftan selbî bir iștirak fiilin kolaylıkla işlenmesini temin ettiggi hallerde kanunun kabul ettiği amüzaharet" "muavenet" (m. 65 , bent III) hallerine dahil olabilir.

$\mathrm{Bu}$ sebeple bir kimsenin suç mahallinde sadece bulunması suçun işlenmesine tesir etmiş ise selbî iştiraki kabul etmek lâzımdir. Fakat şüphesiz «bir kimsenin suç mahallinde fiilen bulunmus olması

(33) Prins, n. 551.

(34) Roma hukukunda, oğlun babasın öldürmek kastı olduğunu bilen kimsenin ,baba ile hiçbir akrabalık rabıtası olmasa ile onu keytiyetten haberdar etmemesi suç sayslyyordu, bu hususta Nocito, s. 357.

(35) Manzini n. 483.

(36) Selbi iștirakin mümkün olduğu hakkında Florian, s. 45; Pozzolini n. 174; Majno ת. 347 .

(37) Manzini'nin selbî suçlar hakkindaki nazariyesi. bu hususta bk. Manzini C I. s. 456; C II. 293. bu nazariyenin izahı hakkıłda Kantar s. 138.

(38) Fransız yargıtay kararı, Dalloz s. 370: "passif bir iștirak kanunun kabul ettiğg fer'î iştirak şekillerinden hiçbirine dahil olmaz. Bu sebeple bir müessir fiil sahnesinde hazır bulunduğu halde passif kalan şahidin manevî fer' fail olarak mahkûm edilmesi yolsuzudur». 
ve suç teşkil eden fiilin başkașı tarafından işlenmesi o kimsenin iştirakini isbata yetmez. Bundan başka iştirak hususunda sarih veya zımnî bir iradenin vücudu lâzmcìr”. (39).

Selbî iştirak hali yalnız fer'̂̀ failliğe değil, aslî failliğe de meydan verebilir, bu sebeple İtalyan Yargıtayı «hırsızlığın işlenmesine passif bir surette yardım ederek müsaade eden kimsenin çalınan şeyden istifadeye iştirak etmemiş olsa bile, hırsızlığa hemfiillikten mesul olduğunan karar vermiştir (40).

c) İ̧TTIRAKE. TEŞEBBÜS: Kanun teşebbüs müessesesini suçları nazara alarak tâyin etmiştir. $\mathrm{Bu}$ sebeple iştirake teşebbüsün cezalandırılıp cezalandırılamıyacağı tereddüdü mucip olmaktadır. Ortağın cezalandirılmasının müessir bir faaliyette bulunmasi yolundakì maddî unsura dayandiğ 1 gözönünde tutularak, teşebbüs halinde kalmış bir iştirakin müessir bir faaliyet olamıyacağı ve binnetice iştirake teşebbüstin cezalandırılamıyacağı neticesine varılmıştır. Bu sebeple kabul edilmemiş olan suç işleme teklifleri (41) aslî fail olarak harekete geçmesi istenilen kimsenin suçu işlememiş olması hallerinde iştirake teşebbüsü gösteren maddî bazı vâkılar mevcut olsa, bile, ortağa ceza verilemez. O halde ortağın cezalandırılması, aslî failin işlediği suçun cezayı müstelzim bir safhaya intikali şartına bağlanmiştır. Teşebbüsteki bütünlük ancak bu şartın tahakkuku ile tamamlanmış olabilecektir. Fakat kanunun bazı kışkırtmaları (teşvik) müstakil suç saydığı hallere (42) iştirake teșebbüsün cezalandırdı̆̆ı hususî haller nazarı ile bakmak mümkündür.

Iştirake teşebbüs umumiyetle reddedilmekte ise de (43) teşebbüste suç işleme kararının haricileşmesini kâfi gören đüşünce tarzı (44) esas tutulacak olursa iştirake teşebbüsü cezalandırmak kabil olacaktır. Aslî failin suç işlememiş olması halinde, bile, ortağmn faaliyeti onun cemiyet için tehlikeli bir şahıs olduğunu gösterebilir, bu gibi hallerde iștirake teșebbüsün cezalandırılmasında faide vardır, aslî fail için icra başlangıcı olmiyan bir hareket ortağın suça iştirak

(39) İtalyan Yargitay kararı, Bruno m. 64.

(40) Italyan Yargitay kararı, Bruno m. 63.

(41) Florian s. 48, 49.

(42) 311 inci maddede olduğu gibi; bu hususta Pozzolini n. 176; Manzini n. 485 .

(43) Garratud, C. III, n. 897.

(44) Erem, Ceza kanununun 61 ve 62 inci maddeleri, Adalet dergisi, 945, n. $7 \mathrm{~m} .61 \mathrm{IX}$ Ç; m. 62 III. 
kararını icraya başladığını gösterecek vüzuhu kazarmış ise iştirake teşebbüste icra başlangıcı olarak kabul edilebilir.

§) TEŞEBBỨSE İ̧TTIRAK: Teşebbüs halinde kaimış suçlara iştirak daima mümkündür. «Teşebbüse iştirak tekemmül etmiş suça iştirakteki aynı esaslara dayanır” (45). Teşebbüs hükümleri ile kanun yalnız tekemmül etmiş cürümleri değil, tam veya nakıs teşebbüs halinde kalmış cürümleri de nazara almaktadır. Bu sebeple kanunumuzun altıncı babının başlığı olan "cürüm ve kabahate iștirak" cümlesi teşebbüs halinde kalmış olan cürümlere iştirake mâni bir kayıt değildir.

İştirak halinde işlenmiş teşebbüste vazgeçmenin ortaklar üzerindeki tesirlerini aslî ve fer'î iştirak nevilerine göre ayırmak lâzumdir:

aa. Aslî iştirakte nakıs teşebbüste vazgeçme ve tam teșebbüste faal nedamet hususunda tatbik edilecek kaideler tatbik olunur.

Aslî faillerden (irtikâp edenler, doğrudan doğruya beraber işliyenler) birinin "cürmün ef'ali icraiyesinden ihtiyarı ile vazgeçtiği" hallerde suçtan müsbet bir feragat neticesi husule ggememiş ise, böyle bir vazgeçmenin ortaklar arasindaki münasebete tesiri olamaz, yani ortaklardan birinin suçtan çekilmesi kâfi değildir diğerlerinin hareketine de mâni olması lâzımdır, mâni olmak istemiş fakat mâni olmak imkânımı elde edememiş olması, lehinde bir sebep olarak kabul edilemez, çünkü suç iştirak anında icra ettiği iradî fililin neticesidir ve istirakte kastin icranın bütün safhalarında mevcut kalması şart değildir.

Aynı mütalâa, tam teşebbüste ihtiyarı ile neticeye mâni olma hali için de varittir. Eğer ortaklardan biri "cürmün icrasına taallûk eden bütün fiillern ikmal edilmiş olmasma rağmen neticenin husule gelmesine ihtiyarı ile mâni olmuş ise, bu müessir nedamet diğer ortaklara da sirayet eder ve bütün ortaklar tam teșebbüsten değil, nakıs teşebbüsten mesul olurlar (46).

Aslî istirakte manevî failin (azmettiren) duruminna gelince, azmettirme neticesinde fail icraya başlamıș fakat ihtiyarında olmıyan bir sebepten dolayı fiiller tamamlanmamış (nakıs teșebbüs) veya netice husule gelmemiş (tam teşebbüs) ise azmettiren, maddî fail gibi nakıs veya tam teşebbüsten mesul olur. Maddi failin nakıs te-

(45) Suman m. 63; III.

(46) Tam teşebbüste faal nedamet halinde bulcnana nakıs teșebbüs hükümlerinin tatbiki hakkında, Erem, adı geçen makale, m. 62, III A. 
şebbüste ihtiyarı ile vazgeçmesi teşebbüsün hukukî mevcudiyetini ortadan kaldırmaz, böyle bir vazgeçme ancak vazgeçen için bir cezasızlık sebebidir ve bbyle şahsî bir sebebin azmettirene teşmiline imkân yoktur, maddî failin ihtiyarı ile vazgeçmesi azmettiren bakımindan "ihtiyarı haricinde bir sebep» ten başkan bir şey değildir.

Maddî fail, tam teşebbüste neticenin husulüne mâni olmuş ise, kendisi nakis teşebbüsten, azmettiren tam teşebbüsten mesuldür, çünkü azmettirenin harekete geçirdiği vasita (maddî fail) suçun husulüne muktazi her şeyi ikmal etmiştir. Maddî failin neticeye mani olması azmettirenin iradesi ile ilgisi olmyyan bir haldir.

Eğer nadim olan azmettiren ise ve fail suçu işlemeğe başlamiş ise veya işlemiş ise bu nedametin tesiri olamaz. Çünkü müessir olamiyan bir nedametin değeri yoktur. Fakat azmettiren fiillerin ikmaline veya neticenin husulüne failin hareketini durdurmak suretile mâni olabilmiş ise azmettirenin durumu değişir ,azmettiren nakıs teşebbüs sahasında, faili vazgeçmeğe mecbur etmiş ise fail nakıs teşebbüsten mesul olur, azmettiren ceza göremez, azmettíren tam teşebbüs sahasında neticeye mâni olmuş ise fail tam teşebbüsten azmettiren nakıs teşebbüsten mesuldür.

bb. Aslî faillerin nakıs teşebbüsten vazgeçmeleri, tam teşebbüste faal nedametleri fer'î faillerin cezasına tesir etmez (47).

Fer'î failin vazgeçmesi, hareketi suçun husulünde tesir icra etmeden evvel vukua gelmiş ise, ortada henüz fer'î iştirak mevcut olmadığından ceza vermekte bahis mevzuu olamaz. Eğer fer'î failin nedameti suçu icraya başlamasınà mâni olmak suretile faal bir nedamet halịnde ise yine cezalandırlamryacaktır, çünkü fer'î failin müdahalesi ile fer'î iştírakin şartı olan asıl fiilin işlenmiş veya hị̧ olmazsa işlenmeğe başlanmış olması hali tahakkuk etmemiştir.

Eğer suçu teşkil eden fiil işlenmeğe başlandıktan sonra fer'î fajlin vazgeçerek mâni olucu hareketlerde bulunması sebệi ile suçun tekemmülü için gereken hareket tamamlanmamış ise, aslî faíl için ortada nakıs teşebbüs mevcuttur, çünkü aslî failin ihtiyarınđa olmIyan bir sebeple cürmün husulïne muktazi hareketler tamamlanmamıştır. Bu durumdaki fer'î failin cezaya çarpilmaması lâzım gelecèğini sanıyoruz, hakkında 62 inci maddenin ikinci flkrasının tatbiki ile cezadan muaf tutulması yerinde olur (48). Fakat bu durum sarahaten «müteşebbis» ten bahseden bu flkra hükmünün lâfzına aykurı

(47) Manzini n. 485.

(48) Aksi mutalâa Manzini n. 488. 
düşmektedir, fakat bu fukranin vaz'ı sebebindeki cezà siyaseti mülâhazalarina tamamen uygundur.

Suçun tekemmülünden evvel, fer'î fail vazgeçer ve fakat aslî faili feragata razı edemezse fer'î failin böyle bir vazgeçmesinin tesiri olamaz. Çünkü kaideten cezayı müstelzim bir iştirakten sonraki vazgeçme, fer'î faili cezadan kurtaramıyacaktır. Çünkï iştiraki tazammun eden fiil fapldığı andan itibaren bu fiil kendine has olan tesiri yani suçu teşvik, kolaylaştırma ve saire gibi tesiri icra etmiştir. Bu sebeple suçu işlemek için talimat vermiş, sil:h tedarik etmiş olan kimseler cezadan kurtulmak için bilâhare failleri durdurmak maksadile iktidarlarında olan her şeyi yapmış, hattâ salâhiyetil makamlara ihbarda bulunmağa bile tevessül etmi șolduklarmi isbat etseler cezadan kurtulamazlar, feragatleri gẹ kalmıştır, çünkü suçtaki rolleri sona ermiş ve iştiraki teşkil eden maddî fiil tekemnül etmiştir (49).

d) TAMAMLANMIŞ SUÇ: Tamamlanmıs suça iştirak edilemez, çünkü iştirak suçun husulünde hisse sahibi olmağı icap ettirir. Bir kimsenin hiç bir müdahalesi olmaksızın tamamlanmış suça bilâhare iştirak tasavvur edilemez. Suçun tamamlanması ile iştirak imkânları sona erer, suçtan sonraki müdahaleler kanunun sarahaten kabul ettiği yerlerde müstakil suç olabilirler, cürüm işliyenleri saklamak, cürüm delilleri yoketmek (m. 296) cürüm eşyasını satın almak, saklamak (m. 512) suçlarında olduğu gibi. İşlenmiş bir suçun onu tasdik ve kabul edene atfl, ceza hukuku prensiplerine uymaz, tasdik ve kabul ,diğer şartlarda mevcut ise müstakil suç olaiblir (m. 312) (50).

III. MUHTELIF SUÇLAR BAKIMINDAN JSTIRAK: A.ksine kanunda sarahat buIunmadıkça (51) ve suç mahiyeti itibarile iştirake müsait oldukça, iştirak hükümleri tatbik olunur.

Bu sebeple kendiliğinden hak aima (52), hiyleli iflàs (53) evlenme maksadı ile kaçirma (54) suçlarmnda iştirakin mümkün olduğuna karar verilmistir.

Bazı suçlar kanunda sarih bir kayıt bulunmasa bile, iștirak

(49) Garraud C. III n. 897 VIr.

(50) Pozzolini n. 177.

(51) Fransiz yargitay karar, Dalloz s. 369.

(52) Italyan yargitay karari, Bruno m. 63.

(53) Italyan yargitay karar1, Bruno m. 63.

(54) 1. C. D. 12. 8. 937 esas 4873 karar 3079 tem. kar. 937 s. 295. 
hükümlerinin tabikma müsait değitdir. Bu suçların ayrı ayrı tetkiki faideli olacaktır:

A. TOPLU SUÇLAR: Toplu suçlar ancak birden ziyade kimselerle işlenmesi mümkün suçlardır, zina suç̧unda olduğu gibì. İştirakte suçu teşkil eden fiil tek, fail birden ziyadedir. Toplu suçlarda ise gerek fiil, gerek fail birden ziyadedir (55).

Toplư suçlara iştirak mümkün' olup olmadığını tàyin için şu tefrike ihtiyaç vardır. Mahiyeti itibarile bir ortaklık hareketi teşkil eden bir fiil eğer suçun unsuru veya şiddet sebebi ise bu hareketi yapanlara iştira khükümleri tatbik edilemez. Fakat toplu suçlarda müstakil fail saylanlarm filllerine aslî veya fer'î fail olarak iştirak etmek mümkünđür, çünkü toplu suçlarda failler bir suçun işlenmesine katılmış veya bir suçun işlenmesini kolaylaştırmış değil, her biri müstakillen suçu işlemiştir, ortada yalnız hem zaman olan müstakil fiiller mevcuttur. Toplu suçlar her faile müstakil fail stfatı ile isnad olunur. Toplu suçlara aslî veya fer'î fail olarak iştirak edenlerin iştîraki ise suçun teşkili için zarurî değildir, meselâ zina suçunda kadınla erkek bu suçun hem fiilleri sayllamazlar, her biri kendi suçundan mesuldür, fakat kadını zinaya azmettiren kimse, kadınin suçunda manevî aslî fail, suça yardım etmiş olanda fer'î faildir (56).

O halde netice olarak şu ölçü teklif olunabilir: jştirak hükümleri bir kişi tarafınran işlenebileceği gibi müteaddit kimseler tarafından da işlenebilecek olan suçlar hakkında tatbik olunur (57).

B. MƯTEMADÎ, MŨTESELSİL SUÇ: Mütemadî suça başlamadan evvel meveut bir anlaşmıya dayanan iştirak hali daima mümkündür.

Başlamış fakat ikmal edilmemiş mütemadî sụ̣larà gelince, devam etmekte olan mütemadî suça maddî aslî iştirak kabildir, çünkui sụ̧ devam ettiğine göre suç unsurları ve cezalandırma şartları da tükenmemiştir. Buna mukabil başlamış olan mütemadî suça Manevî - aslî iştirak (azmettirmek) mümkün değildir, çünkü fail sựu işiemeğe azmettiricinin faaliyetinden evvel başladığmdan azmettirme bahis mevzuu olamaz.

Başlamış, fakat ikmal edilmemiş mütemadî suçlarda fer'î işti-

(55) Pozxolini. n. 163; bu nevi suçlara kollektif suç, iki taraflı suç isimleri de veritmekte (Manzini n. 488), veya bu nevi ortaklı̌̆g zarurî iştirak (participation nécessaires) (Ligoz s. 95 n. 3) adt da verilmektedir.

(56) Manzini n. 488.

(57) Pozzolini n. 163 , 
rakin her şekli mümkündür, mütemadî suçun devamma teşvik, devam kararını takviye, suçun ne suretle devam edebileceğine dair talimat vermek ve diğer bütün fer'î iștirak faaliyetleri bu nevi iştirake meydan verir.

C. MUAYYEN SIFATI HAİZ KIMSELERIN SUÇLARI: Suçun teşekkülü için kanunun failde muayyen bir sıfatı bulunmasını şart saydığı. hallerde kendisinde bu sıfat bulunmiyan ortak bu sıfatı haiz bulunan bir kimsenin suçuna iştirak edebilir (58). Bu sebeple bir memurun, bir ruhạî reisin suçuna bu sıfati haiz olmıyan kimselerin iştiraki mümkündür. Fakat faildeki bu sıfatın aslî veya fer'î ortak tarafından bilinmiş olması lâzımdır (59). Bu sebeple memurların memuriyetlerine taallûk eden suçlarma memur olmıyanlarm (bilerek" iştirak etmelerinin mümkün olduğu yolundaki yargitay içtihadl yerindedir (60).

C. IŞLEYENI BILİNMIYEN ADAM ÖLDÜRME VE MU̇ESSIR FílL (Faili gayri muayyen katil ve müessir fiil) (Complicita corrispettiva) (61): Kim tarafından işlenmiş olduğu bilinmiyen adam öldürme ve müessir fiil suçlarında fiili işliyenlerin hepsinin cezalandirılması ve fakat bu cezanın indirilmesi keyfiyetine "işliyeni bilinmiyen adam öldürme ve müessir fiiln denir. Kanun bu hali 463 üncü maddesinde göstermiş ve bu hükmün adam öldürme ve müessir fiil suçlarmı teşkil eden "fiilleri birkaç kişi birlikte yapmış olup ta failin kimolduğu belli olmazsan tatbik edileceğini beyan etmiştir. $\mathrm{Bu}$ hükümde kullanılan tabirlere nazaran 463 üncü maddenin münhasıran aslî iştirak hükümlerine istisna teşkil ettiği neticesine varmak lâzımdır (62). Çünkü fer'î ortaklar suçu teşkil eden fiilleri "yapan" lar değil, yapılana yardım edenlerdir.

İşliyeni bilinmiyen adam öldürme ve müessir fiil hallerinde suçlulardan bazıları (463 üncü maddeye göre karşlıklı ortak, diğerleri de 65 inci maddeye göre fer'î fail olarak kabul edilirse, fer'î faillerin cezasını tâyin de esas karşıllklı ortakların cezası değil, suçun faili hakkındaki mevzu cezadır) (63).

(58) Manzini n. 488 .

(59) Manzini n. 488 .

(60) C. Gk. 21, 2. 944 esas 3 - 20 karar 23.

(61) Bu tabir Majno tercümesinde «faili aslisiz feran zimethallik» tarzında dilimize çevrilmiştir, s. 455.

(62) Aynı yorum, Manzini n. 489; aksi yorum Altavilia n. 192.

(63) İtalyan yargitay kararı Bruno m. 64. 
İştirak hükümlerine istisna teşkil eden bu hüküm (şüphe sanığın lehinde yorumlanır) kaidesinin kanunî bir tatbikından ibarettir (64) ve esasa taallûk etmekten ziyade usule aittir. Bu hüküm yersiz bir hükümdür, suçu işliyeni bulamamaktan ileri gelen adlî iktidarsızlığin, ortağa kendine ait olandan daha ağırının tahmili için bir sebep olamaż, diğer taraftan cezadaki musavat ortakların kötülüğündeki eşitliğinden değil, sadece delil yokluğundandır (65).

D. KAVGA: Bir kimsenin ölümü veya yaralanması ile neticelenmiş bir kavgaya katılmış olmak halini kanun ayr bir hüküm ile cezalandırmıștır (m. 464), böyle bir kavgada mağdura el kaldırmış olmak hali bir suç teşkil ettiği gibi cezası daha hafif olmakla beraber, sadece kavgaya dahil olmak ta suçtur.

Müteaddit kimselerin bir araya gelmesine ihtiyaç gösteren kavga hâdisesinde iki mesuliyet hali mevcuttur: Kavgaya öldürmek veya yaralamak kastı ile katılmış olanin mesuliyeti adam öldürme veya yaralama mesuliyetidir $(66)$, bu neticeyi istememiş olmakla beraber ölüm veya yaralama ile sona eren kavgaya iştirak edenlerin mesuliyeti ise 464 üncü maddeye girer, bu sonuncủ mesuliyet aslî veya fer'î bir işitirak hali değildir, kavgaya katılmış olanın durumu suis generis bir aslî suçluluk (67) yani müstakil bir suçtur.

464 üncü madde iştirak hükümlerine bir istisna sayllamaz, çünkü bu madde hususî bir fiili suç mevzuu saymiş ve iştirak hükümlerine ne sarih, ne de zmnî bir istisna komamıştır, bu selseple kavga esnasında işlenen veya işlenilmesine iştirak edilen suçlar kavga hükmüne değil (68) iştirak hükmüne tâbi olmakta devam ederler.

\section{İ K I N C t B ÖL U ISTTIRAKIN NEVILERI}

Iştirak şekilleri kanunen tâyin edilmiştir. Bu sebeple kanunî iştirak şekillerine girmiyen bir birleşmiye, iştirak hükümlerinin teşmiline imkân yoktur. Bazı müellifler iştirak şekilierinin kanunda tasrih edilmesinde, vatandaşların adalet karșısında emniyetlerini sağ-

(64) Ayni mahiyette Majno n. $\mathbf{3 5 5}$.

(65) Pozzolini n. 179.

(66) Pozzolini n. 179.

(67) Altavilla n. 178.

(68) Manzini n. 489. 
lıyan bir vasıf görmektedirler, «eğer kanun hangi hallerde iştirakin mevcut olacağını tâyin hususunu hâkimlerin takdirine bıraksa idi, adalete hudutsuz bir kuvvet tanımış ve vatandaşlarm emniyetini ortadan kaldırmis olurdu» (1).

Bu düşünce kuvvetii esaslara dayanmamaktadır. İ̧̧tirak halinde nasıl hareket olunacağının kanunda gösterilmesi ve fakat hangi hallerin iştirak sayılacağı hususunun hâkimin takdirine burakılmașı daha doğrudur. Bütün iştirak hallerinin kanunda tâyini usulü daima eksik kalma tehlikesi arzeder... Hâkimin iştirak halini tâyin serbestisinin vatandas emniyetini tehlikeye koyması da varit olamaz. Yeni Ceza kanunlarında iştirak hallerini sayma usulü terkedilmiştir.

Bir suçta ortaklık mesuliyet sahibi kimseler arasında husule gelebilir. Ceza mesuliyeti olmıyanın fiiline (akıl malûlü, küçük gibi) katılmada iştirak hükümleri tatbik edilemez, çünkü bu gibi hallerde mesuliyeti olmuan kimse ortağın elinde bir alettir, mesul onu kullanandır, çünkü bu kimse, mesul olmryandan "şuursuz bir enerjiı (2) gibi istifade etmistir (3).

Doktrinde iştirakin muhtelif taksimlerine tesadüf olunur. Aslî fer'î; maddî - Manevî; Mukaddem - Hemzaman; Zarurî - Zarurî olamiyan istirak taksimleri ekseriyetle kabul edilmiş tasniflerdir. Kanunumuz sarahaten aslî - fer'î iştirak tefrikini kabul etmiş ve bu iki iştirak nev'ini ayrı maddelerde göstermiştir (m. 64, 65).

Kanunda sarahaten kabul edilmiş olan aslî - fer'î iştirak tasnifine esas itibarile pozitivistlerde muhalif değildirler, yainız klâsik mektebin yaptığı gibi, munhasıran objektif unsurları değil, aynı zamanda suç işleme saikının da nazara alınmasını isterler. $O$ halde pozitivistlere göre hâkime suçlunun karakteri suç sebepleri, iştirakin tesir derecesini gözönünde tutarak aslî ve fer'î iştiraki tefrik bir ceza yerine diğgerini tatbik hususunda takdir hakkı tanılacaktır (4).

Kanunumuzun koyduğu esaslara göre aslî iştirakte suçun «icrasına iștirak» edilmektedir (5), bu husus 64 üneü maddeden sarahaten anlaşıImaktadır. Fer'î iştirakte ise ortaklarm faaliyeti icranır bütününe nazaran fer'î bir vasıf arzeder.

Aslî iştirakte ortakların her birinin yaptı̆̆ kànunen memnu

(1) Prins n. 552 .

(2) Manzini n. 475 .

(3) Pozzolini n. 178.

(4) Pozitivistlerin bu sahadaki düşünceleri hakkında Pozzilini n. 170.

(5) Manzini n. 472. 
olan füillerdir, halbuki fer'î iştirakte ortakların hareketleri müstakillen nazara alındıkta suç teşkil etmez, aslî faile bıçak tedarik etmek gibi. Bu nevi fiillerin suç oluşu, haddi zatmda suç olan diğer bir fiil ile birleşmiş olmalarmdan ileri gelir (6).

Aslî iştirak fer'î iştirakten suçun teşekkülündeki hisseleri bakımından ayrıldığına göre müstelzim olacakları cezanın da farklı olması lâzım gelecektir. Fakat suçun bütün ortaklarına müsavi ceza vermek fikri de müdafaa edilmiştir. Ortolan, başisasmm fiiline iştirak edenin suçtan mütevellit bütün ihtimalleri de ve binnetice bundan mütevellit cezaları da kabul etmiş olduğu fikrindedir (77). Bazı alrian müellifleri de başka bir gerekçe ile, aynı fikrì müdafaa ederler: suç, herhangi bir hâdise gibi onu husule getirecek olan sebep ve şartlarm birleşmesi neticesidir, bu sebeplerden her biri yalnuz başına değil ve fakat diğer sebep ve şartlarla birleşerek suçu meydana getirir. Bundan her şartın suçun husulü için zarurî olduğu neticesi çıkar, çünkü bunlardan biri olmasa idi suç meydana gelmiyecekti. Bu sebeple bütün şartlar arasında objektif bir değer eşitliği vardır. O halde suça katılanların hepsine aynı cezanın veriłmesi lâzimdir (8).

Ortaklara müsavi ceza verilmesi fikri, kanunumuzca kabul edilmemiştir. Her ortağın hissesindeki aslî veya fer'î vasfa göre ceza görmesi mesuliyette objektif unsuru esas tutan kanunumuzun umumî sistemi iktizasindandur.

I. ASLÎ İ̧TIIRAK: Aslî iştìak aslî faillerin arasındaki iştiraktir. Aslî fail meyhaz kanunun gerekçesine göre usuçu teşkil eden fiili işliyen kimse" dir (9). "işlemek" tâbiri selbî hareketleri de içine alır. Bir fiili işlemiş sayılmak için onu bizzat yapmış olmak şart değildir. İstediği suç neticesini husule getirmek için tabiî bir kuvveti (ateş vesaire gibi) yahut bir hayvanı (mağdura karşı tahrik edilmiş azgin bir köpek) kullanan kimse de suçun failidir (10). Ceza mesuliyeti olmıyanı bir alet gibi kullanan da suçu işliven kimsedir.

Aslî iştirak maddî ve manevî olmak üzere ikìye ayrilır. Aslî maddî iştirak 64 üncü maddenin birinci fikrasunda, aslî - manevî iştirak aynı maddenin ikinci fıkrasında gösterilmiştir.

(6) Bu hususta Carraud C. MI n. 876.

(7) Pozzolini'den nakien, n. 168.

(8) Bon Buri'nin fikri, Pozzolini'den naklen.

(9) Pozzolini n. 180.

(10) Logoz s. 93 . 
A. ASLÎ - MADDî İSTTRAK: Aslî - madîi iştirak suçu “irtikâp edenler, doğrudan doğruya beraber işliyenler" arasındaki iştiraktir.

Kanun "irtikâp edenler, doğmudan doğruya beraber işliyenier" den bahsetmekte fakat bunlarm faaliyetlerinin mahiyetini sarahaten göstermemektedir:

a) SUÇU IRTIKÂP EDENLER: Suçu irtikâp edenler, cezayı müstelzim fiili teşkil eden hareketleri yani suçu łoğrudan doğruya husule getirecek hareketleri yapanlardir.

Fakat bunu suçu tekemmül ettiren harekete yani son icra hareketine hasretmek dogru değildir. Bu sebeple şu tefrik yerindedir:

Suçu irtikâp edenler arasında ya basit, ya mürekkep bir iştirak haline tesadüf olunur. Aynı binaya ayn zamanda ateş vermek, aynı mağduru müteaddit kimselerin bıçaklaması birinciye misaldir. Íkinci hal husule gelmesi derece derece muhtelif faaliyetin cereyanma ihtiyaç gösteren suçlarda kendini gösterir, bu tarzda ișlenmiş suçlarda muhtelif hareketler aynı gayeye matuftur ve suçun husule gelmesi için hepsine ihtiyaç vardır, kalpazanlı suçunda sahto para resminin çizilmesi, baskıya geçirilmeși, basılması hareketleri gibi (11).

b) DOĞUDAN DOĞRUYA BERABER ISSTLYYNLER: Suçu doğrudan doğruya beraber isliyen aslî faillerin faaliyeti mahihiyetleri bakımından fer'îdir. F'akat maddî sekilleri ve suçun icrası ile hem zaman oluşları onları aslî bir iştirak faaliyeti haline inkilâp ettirir. Doğrudan doğruya beraber işliyenler, suçu meydana getiren hareketleri icra etmemiş olmakla beraber irtikâp edenle birlikte sucun tahakkukuna iştirak etmişlerdir. Bunlarm faaliyeti ne suçun unsuru ve ne de şiddet sebebidir, fakat suçun icrasında doğrudan doğruya müessir olan bir faaliyette bulunmuşlardur ve bunların faaliyeti olmaksızan irtikâp eden suçu işlemeğe muvaffak olamazdı. Bu sebeple nöbet bekliyen polis memuru vakada hazrr olduğu halde hrssizların bir eve girmelerine evveice aralarında mevcut bir anlaşmiya müsteniden müsaade ederse suçu doğrudan doğruya beraber ișliyen aslî fail durumuna düşmüș olur. Yine aynı sebepledir ki, hırsłzlıkda gözcülük edenin suçu doğrudan doğruya beraber işlemek tarzında aslî fail olduğuna karar verilmiştir (12).

Kuvvetli olan mağduru bir kimsenin tutması diğerinin öldürmesi veya parasın alması hâdiselerinde mağduru tutan suçu doğrudan

(11) Manzini n. 472 .

(12) Italyan yargitay karar1, Manzini s. 315 not 6; Bruno m. 63 . 
doğruya beraber işlemiş olan kimsedir. Eğer suçu irtikâp edenlere suç faaliyetinde daha geniş bir hisse verilirse bu şahsın bir uirtikâp eđen» sayılması da mümkündür. Fakat böyle bir münakaşanın tatbiki değeri yoktur.

Doğrudan doğruya beraber işliyenlerin faaliyeti mahiyeten fer'̂̂ olmasına rağmen yukarıda söylenilen sebeplerle bu nevi ortaklarda aslî fail olarak kabul edilmiştir. Beraber işliyenlerin. irtikâp edenlerin faaliyeti bir kül teşkil etmesi, bu suretle aralarmda çok yakın bir iştirak halinin bulunması, doğrudan doğruya beraber işliyenin de suçu irtikâp eden kadar kesin bir suçluluk iradesine sahip olması doğrudan doğruya beraber işliyenlerin aslî fail seviyesine çıkarılmasina sebep olmuştur (13).

B. MANEVî - ASLÎ IŞTİRAK: Başkasıinı sụ̧ işlemeğe azmettirenin iştiraki demektir. Kanunun kullandığ ${ }_{1}$ "azmettirmek» tâbiri manevî iştirak için elzem olan psikolojik fiilin mahiyeti hakkındaki bütün tereddütleri izale etmektedir. Suçun sebebi, suç işleme niyetinin azmettirilene nakledilmiş olmasıdır. Böylece işlenmiş suçlarda suçu işliyenin faaliyeti gerisinde suça sebep olan yani azmtetiren kimse bulunur. Faildeki suç fikri ve suç kararı munhasıran azmettirenin eseridir.

"Azmettirme» 1stılahı suçun ilk ve müessir sebebini yaratmak mânasına gelir. $O$ halde suç fikrini uyandırmış olmak, suçun mânevî ortağı olmağa yetmez, bu kararm icra safhasına intikalini yani suçun müessir sebebi olmayı temin edecek derecede kesif bir manevî faaliyete ihtiyaç vardur.

Kanun azmettireni suç işliyenlere benzetmiş ve (aynı ceza» yı vermiştir. Azmettirenin suçu işliyene benzetilmesi kanunî bir faraziye değildir ,azmettirenin faaliyeti ile husule gelen netice arasinda illiyet bağı mevcut olduğundan azmettirenin haddi zatında bir nevi failden başka bir șey saylamaz. Manevî iştirakin daima fer'î bir 'iştirak telâkki edilmesi fikri kabule değer bir fikir değildir (14).

Azmettirenin hareketi ile suç arasında illiyet bağı bulunmast yolundaki kaideđen şu netice çıar: suç işlemek kararmı zaten evvelce vermiş bulunan kimseyi "azmettimek» bahis mevzuu olamaz.

Azmettirme, azmettiren ile edilen arasındaki ferdî bir münase-

(13) Doğrưden doğruya beraber işleỵenlerin aslî fail sayllmaș sebebi hakkında meyhaz kanunun gerekçesi, kirala verilen rapor; Pozzolini n. 186; Manzini n. 472 II, III.

(14) Bu hususta Rossi s. 189, 190. 
bete dayanır. Bu sebeple suç işlemeğe tahrik (m. $\mathbf{1 1 1}, 312)$ eden ortak değil, müstakil bir suçun failidir.

a) AZMETTİRMEDE MANEVÎ UNSUR: Manevî - aslî iştirakin kabulü iştirak hakkındaki umumî şartlara bu meyanda kastın mevcudiyetine de bağlıdr. Bu sebeple kastssz bir azmettirme, bir kimseyi suçun manevî ortağı haline sokmaz. Taksirli bị azmettirme kabili tasavvurdur. Fiilin istendiği, fakat neticenin irade edilmediği hallerde taksirli azmettirme haline tesadüf olunur. Muayyen olmıyan bir söz, ihtiyatsızca bir hareket neticesinde bir şahıs suç işlemeğe karar vermiş olabilir (15). Bu sözü sarfeden veya hareketi yapan kimse başkasının kastî fiiline taksirli bir azmettirme ile karışmıs olur. Miyop bir kimsenin ava gitmeğe ikna edilmesi (16) ve bundan bir kazanın vukua gelmesi halinde de taksirli bir suç, taksirli bir azmettirme ile müdahale bahis mevzuu olabilir. Fakat bütün bu hallerde azmettiren kimseye 64 üncü maddenin ikinci frkrasını tatbika imkân yoktur. Çünkü kanun ancak kasdî - manevî ortaklığı kabul etmektedir, şahıs kusurlu hareket etmiş olsa bile taksirli bir azmettirmé ortaklık sayılamaz, çünkü kanunumuzun sistemine göre ancak kanunun açıkça gösterdiği hailerde taksir cezayı müstelzimdir.

Kanun, hilâfma sarahatı ihtiva etmediği hallerde, münhasıran kastı arar. Bu sebeple azmettirmenin kasta dayanması kâfidir, saikin ehemmiyeti yoktur. Bu kaidenin tatbiki ehemmiyeti vardrr: Bașkasinn, tevkif ettirmek, meşhut suç halinde yakalatmak, hükûmetten ikramiye almak (17) gibi maksatlarla başkasını sue ișlemeğe azmettirmiş olan kimse manevî - aslî fail sayılmalt mıdır? Meselenin umumî prensiplere göre halledilmesi lâzımdır. Kanun isstirak saikini aramadığma göre başkasını, suçtan husule gelecek menfaatten gayr? saiklerte de suça ikna eden kimse azmettiren kimse sayzlmalddrr.i Böyle bir azmettirme neticesinde harekete geçen failin suç teșkil eden faaliyetinden azmettiren kimse, saiki ne olursa olsun mesul olur.

Azmettiren kimsenin suçları takip ile mükellef bir devlet memuru olmasi ve faili yakalamak maksadı ile hareket etmesi (hïviyetini saklyyarak eczactyı yasak bir maddeyi reçetesiz satmağa ikna eden polis memuru gibi) halinde bazı tereddütler ortava çıabilir. Zannımıza göre umumî prensipleri buradá da tatbik etmek ve saiki

(15) Bu hususta $\log \alpha$ m. 24 n. 1

(16) Manzini n. 473.

(17) Logoz m. 24, n. I; Manzini n. 474. 
ne olursa olsun her şahsı azmettiren kimse saymak ve fakat kanunun veya salâhiyetli merciin emri ile hareket olunmuş̧ ise ve 49 uncu madde gereğince bu hususta aranılan şartlar mevcut ise cezadan muaf tutmak yerinde olur (18). 49 uncu maddedeki şartları aramak mecburiyeti zabıtanın muvafık sayılamıyacak bu nevi araştırma usullerini kullanma temayülünü tahdit edebilir.

b) AZMETTIRMEDE MADDÎ UNSUR: Manevî bir iştirak şekli olan azmettirmede esas itibarile maddî bir unsur bahis mevzuu değildir, fakat azmettirenin mesul tutulabilmesi, işletmek istediğ̣i fiil lin cezayı istilzam edecek safhaya intikali ile mümkündür. Bu sebeple azmettirenin cezalandurılması için azmettirmiş olması kâfi dẹ̆ı ldir. Failin hazırlayıc hareketlerden öteye gitmemes: halinde azmettirilene ceza verilemez, fïlin hiç olmazsa nakıs tesebbüs safhasına geçmesi lâzımdir.

Bu sebeple azmettirmeğe teşebbüs cezalandirilamaz. Azmettirme muvaffak olmuş farzedilse bile herhangi bir sobeple failin suçu işlememiş olması maddî unsurun meveut olmaması neticesini doğurur. Bununla beraber bazı yabancı kanunlar azmettirmeğe teşebbüsü sarih bir hükümle cezalandırmıșlardır (19)..

Dïzme suç (reato putativo) husule gelmesine imkân olmıyan bir suç olduğundan ne failin ne de azmettirenin cezalandirnlmasina imkân yoktur. Bir kimseyi muhafaza altında bulunan bir evde hirsizlık yapmağa ikna eden polisin itimadın kazanmış bir kimsenin hareketigibi (20).

Suç teşkil etmiyen gayrı meşru bir fiile azmettirmèk, kanunun sarih bir hükmü mevcut ise müstakil suç olacak cezalandırılır, başkasını intihara azmettirmek gibi (21).

(18) Bu mesele hakkında Manzini n. 474; Italyan yargıtayı böyle bir hâdisede zabitanın böyle bir usul kullanmasının doğru olmadığına, fakat aldkr tılan kimsenin işlemiş olduğu suçun da, her bakımdan tamamile tekemmül etmiş sayılması lâzımgeldiğine, memur için ortada bir mutifiyet sebebinin mevcut olduğuna karar vermiştir; Manzini s. 322 not 3.

(10) İsviçre CK. m. 24 f. 2: (başkasın bị cürüm işlemeğe azmettirmege teşebbüs eden kimse bu sựun teşebbüsü için konulmuş ceza ile cezalandulır).

(20) Manzini n. 474.

(21) TCK nunun 454 üncï maddesinde kullantlan tabirler hakkında bk. s. 9 not 2 . 
Neticesiz kalmıs azmettirme kaideten cezalandmlamaz, kanunun sarih hükümlerle koyduğu istisnalar mevcuttur (22).

Azmettirenin manevî iştirak sahašnda kalmasi suçun maddî̀ oluşuna katılmaması lâzımdır. Eğer herhangi bir şekilde suçun işlenmesine katılmış ise, faaliyetinin şekline göre suçu irtikâp eden veya doğrudan doğruya beraber işliyen kimse durumuna düşer. $\mathrm{Bu}$ yer değiştirmenin bilhassa suçu işliyenin onu işlemekte "şahsî menfaatis bulunduğu hallerde ehemmiyeti vardır..

C. AZMETTIRME VASITALARI: Kanun yainz neticeyi ele almakta ve hangi vasitalarla olursa olsun, azmettirilmiş olmayı kâfi görmektedir.

Vait, korkutma, tehdit, medih (23) sarih bir teklif, ihtiraslarn tahriki, gizli bir cemiyetten bahsetme (24) vesaire gibi bütün vasıtalar kullnılmış olabilir. Vasıtaların elverişliliğini takdirde azmettiren ile azmettirilen arasındaki münasebetin mahiyeti her birinin irade kuvvetlerinin derece farkı, telkin etme, edilmı kabiliyetleri ve bu gibi diğer bütün unsurlar nazara alınmahdır.

Bu ölçülerin tatbiki ile "talebelerini ceza vermek yahut imtihanda döndürmek tehdidi ile evlerinden bazt şeyler calmağa ve kendisine getirmeğe sevkeden öğretmenin rzmettirici olduğuna" karar verilmistir (25).

Azmettirenin fail ile doğrudan doğruya temasa geçmiş olması şart değildir. Aract kullanmış olması durumunu deşiştirmez. Her ne kadar azmettiren ile ettirilen arasında ferdî bir münasebete ihtiyaç varsa da. azmettirenin diğerini tanımış olmas şart değildir, tanısmıyanlar arasinda da böyle bir münasebet husule gelebilir.

C.. AZMETTIRME ŞEKILLERI: Azmettirme ile ceza mesuliyeti olmyyan bir kimseyi bir suçta icra vasita olaral kullanmak halini biribiri ile karıştırmamalıdır. Ceza mesuliyeti olmiyanı icra vasıtası olarak kullanan kimse azmettiren değil. suçu işliyen kimse sayı$\ln (26)$.

Azmettiren ile ettirilen arasındaki ortaklık muhtelif. șekillerde kendini gösterebilir:

(22) 172, 242 inci maddelerde olduğu gibi.

(23) Manzini n. 474.

(24) Manzini n. 473.

(25) Italyan yargitay kararı, Manzini n. 473.

(26) Majno n. 335. 
1) SUÇTA VEKÂLET: Failin kendinin değil azmettiren hesabına suçu işlemesi halinde fail ile azmettiren arasindaki münasebet hususî hukuktaki vekâlet aktinden doğan duruma benzer bir durum ortaya çlkarır, bu hale ceza doktrininde suça vekâlet adı verilir.

Böyle bir anlaşmya müekkilin korkaklığı veya kendisini tehlikeye atmak istememesi, yahut kendisi seyahatta veya uzak bir memlekette iken suçun işlenmesini istemesi gibi hallerde tesadüf olunur.

$\mathrm{Bu}$ anlaşma vekilin kabüü ile tamam olur. $O$ halde suçta vekâlet bir anlaşmadır ki, onunla bir kimse (müekkil) kendi menfaatine bir suç işlemeyi diğer bir şahsa (vekil) tahmil eder ve bu şahsın kabulii ile akit tamamlanir.

Ceza doktrininde yer alan bu mefhumun hususî hukuktaki vekâlet akti ile hị̧ bir alâkası olmaksızın tetkik edilmesi lâzımđ̀ır. Hususî hukukta vekâlet. aktine ait hükümlerin hiç birinin suçta vekâlet mefhumuna tatbikıına imkân yoktur. Çünkü suç işlemek hedefini güden bu vekâlet gayesi bakımından batıl bir akittir. Bu sebeple suçta vekâletin hukukî bir değeri yoktur.

Suçta vekấletin teklif ve kabul edilmiş olması müstakillen cezayn müstelzim değildir. Anlaşmanın yerine getirilmesine başlanmıई olmalıdır. Çünkü icra başlangıcı henüz mevcut olmadıkça ortaklara ceza verilemez.

Suça vekâlette müekkil ile vekile verilecek cezanın "aynı ceza» yahut "farkh ceza" olması lâzım geleceği hususunda muhtelif sistemler teklif edilmiştir.

Beccaria (27) ortaklar arasinda cezanm farklı olmasinda faide görmektedir, eğer suçu icra edenlere daha fazla ceza tâyin edilmiş olursa başkastna suç işletmek istiyenler, bu iş için adam bulmakta güçlük çekeceklerdir, çünkü cezalar arasındaki fark sebebi ile icra edenler daha fazla tehlikeye maruzdurlar. Fakat ıra edenler suçu işletmek istiyenlerden bu fazla tehlikeye mukabil bir menfaat temin etmis iseler, cezalar müsavi olmalıdtr, çünkü tehlikeler arasındaki fark, elde edilen menfaat farkı ile telâfi edilmiş olur.

Bazı müellifler (28) müekkile vekilden daha fazla ceza verilmesini isterler, çünkü suça astl sebep olan müekkildir. Carmignani gibi diğer bazı müellifler ise (29) vekilin müekkilden fazla ceza görmesine taraftardirlar, çünkü müekkil sadece suçu istemiş vekil ise suçu hem istemiş, hem de icra etmiştir.

(27) Beccaria § XIV; aynı mülalâa Rossi s. 189, 190.

(28) Renanzi, arinaccio'nun fikri, Nocito'dan naklen s. 331 - 335.

(29) Nocito'dan naklen s. 332. 
Giuliani (30) mutavassit bir fikir ileri sürmüs ve ücretli vekâleti (mandato prezzalato) ücretsiz vekâletten (mandato gratuito) ayırmıştır, bu müellife göre ücretli vekâlette vekil ile rrüekkil arasinda cezada musavat, ücretsiz vekâlette cezalar arasında fark mevcut olmalıdır. Çünkü ücretli vekâleti icra edendeki cüret ve müekkildeki cezadan kurtulmak hususundaki ümit biribirine denk gelir, ücretsiz vekâlette ise vekilin suç işlemekte kendine has bir menfaati olacağmdan cezadaki şiddet onu suça sevkeden hissin şiddeti ile mütenasip olacaktır ki bu da belki onu suç işlemekten meneder.

Bu fikir ayrılıklarına rağmen hâkim olan doktrine nazaran vekil ile müekkilin cezası ayn olmalıdrr. Çünkü her ikisi de fenalığın doğrudan doğruya sebebidirler. Faitin iradesini müekkilin iradesinden ayırmağa imkấn yoktur. Çünkü müekkilin iradesi olmaksızın vekilin iradesi husule gelemezdi. Müjekkili iradesini de suçun icrasından müstakil olarak nazara almağa imkân yoktur.

Türk Ceza Kanunu bu son fikri kabul etmiștir, 64 üncü maddenin ikinci fikrasinin sistemi budur.

Vekilin, vekâlet hududunu aşması halinde (mağdurun sadece dövülmesi için verilmiş olan vekâleti aşarak vekil tarafından mağdurun öldürülmesi gibi) müekkilin mesuliyetinin hududunu tâyinde bazı güçlükler ortaya çıkabilir. Bu güçlükler kastı aşan suçlar hakkındaki umumî kaidelerle (31) giderilmelidir.

2) TEŞCI (Consiglio): Bir kimsenin işliyeceği suçtan kendisi için hâsıl olacak faideleri izah etmek suretile, suça azmettirilmesidir. Teşci, vekâlette menfaatin azmettirlene ait olmasi ile aymlu. Teşci ile vekâletin bariz farklarla birbirinđen ayłdedilebilmesi kolay değjldir. çünkü azmettirenin hâdisede hiç bir menfaati olmaması enderdir.

Teşci ile manevî - fer'î iştirak hallerinin (teşvik, suç kararını takviye) birbirleri ile karıștırılması ihtimali vardır. Failde suç iradesi mevcut, fakat șüpheli ve gayrımuayyen olduğı ve teșci üzerine harekete geçmiş olması hali ile o zamana kadar hị mevcut olmiyan suç iradesinin teşci ile tevlit edilmiş olması halinir tefrikinda dikkatli olmak lâzımdır. Çünkü çıarılacak reticeve söre manevî failin göreceği ceza değişecektir.

(30) Nocito'dan nakien s. 331 - 335.

(31) Bk. Kantar, s. 94. 
3) BIRLIK (SOCIETA): Carrara'nun tarifine göre birlik, «iki veya daha ziyade kimse arasinda müşterek menfaatleri için bir suç işlemek hususıindaki anlaşmadır” (32). Birlik, vẹkâlet ve teşciden şu suretle ayrilır: Vekâlette suçtan mütevellit maddî veya manevî menfaat müekkile, teşci de fiili işliyene aittir, birlikte ise bütün ortaklarm menfaatte iştirakleri vardır.

Birliğin umumileşmesi müstakil suçtur (m. 313).

D. AZMETTIRMENIN CEZASI VE SAHSÎ MENFAAT: Azmettirene, ettirilenin işlediği fïlin kanunda yazll cezası verilir (m. 64). Kanunumuzun kabul ettiği hüküm ázmettirenle edilen arsindaki ceza müsavatun y yalnız fiile hasrettirmekte ve fail hakkında hükmedilecek cezayı nazara almamaktadır. Bu sebeple azniettirenin failden daha ağır bir cezaya çarpılması mümkïndür (33). Bu anlayış 64 üncü maddenin ikinci fikrasinm birinci fikraya atıf yapmasindan ve birinci fikrada ise "fiile mahsus ceza" dan bahsedilmesinden ileri gelmektedir.

Kanun azmettirenin cezasını indirici bir hali kabul etmiştir: afiili icra edenin onu işlemekte şahsî bir menfaati olduğu sabit olursa) azmettirenin cezası indirilir.

"Sahsî menfaat) tâbirini meyhaz kanunda olduğu gibi şahsî sebepler (motivi propri) mânasına almalıdır, "şahsî̀ menfaat" tâbirini "ş̧ahsî sebep" tâbirinden daha maddî ve daha dar bìr manaya almak doğru olmaz.

Failin suçu işlemekteki "şahsî sebebe" dayanılarak, azmettirenin cezasının indirilmesine kanun vazımı sevkeden klâsik doktrin bu hükmü şu gerekçe ile izah etmektedir: failde suç işlemek için «şahsî̀ sẹep» mevcut ise azmettirme suçu doğuran yegâne sebep saynlamaz. O halde suçu işliyenin 'iradesi iki kaynaktan gelir: azmettirme ve failde evvelce mevcut şahșî sebepler.

Kanunun bu hükmünü makul bir şekilde izah etmeğe imkân yoktur: fail kendine ait bir sebe pile hareket etmis ise ortada azmettirme mevcut değildir, eğer onu suça sevkeden hem şahsî sebep ve hem de azmettirenin tesiri olmuş ise suç sebepleri arasında azmettiricinin faaliyetinin bulunması, onu sebep olan kimse durumuna sokar.

(32) Pozzolini'den naklen n. 184.

(33) Majno n. 336. 
Bilâkis, azmettirdiği kimsede böyle bir sebebin bulunduğunu bilen kimsenin daha fazla ceza görmesi lâzımdır, çünkü böyle bir sebebe malik olanı. seçmekle azmettiren kimse muvaffakiyetinden daha fazla emin olur ve böyle bir seçim üzerinde clurabilen kimsede suçiuluk hali daha vahim ve ağırdır.

Kanunun bu husustaki hükmünün mantıkî bir değeri yoktur, Toskana kanunundan meyhaz kanuna intikal etmiş olan bu hükmün ancak (ananevi» bir mefhum (34) olmaktan daha jleri gidemiyeceği aşikârdur.

Kanuna göre cezanun indirilmesi için şahsî sebebin "şabit olmasi" lâzımdır. Böyle bir sebebin mevcudiyeti hukukî bir meseleden ziya-

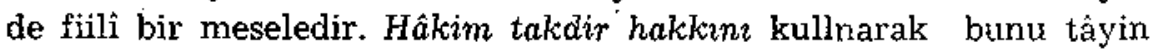
eder, esebep sabit olduğu takdirde cezanm indirilmesi mecburidir. Zanardelli projesinde cezanın indirilmesi ihtiyarî idi. Projenin bu hükmü kanunun sert ve kat'î hükmünden daha ziyade hâdiselerin hususiyetine uyabilecek mahiyette idi. Bu hükmün menşeini teşkil eden Toskana kanununda ise hâkime, failde şahsî sebep mevcut ise azmettirenin cezasını fer'î faillerin cezasına kadar indirmek hususunda bir takdir hakki tanınmış idi (35). Cezayı indirip indirmemekte ve indirecek ise miktarın tâyinde hâkimi serbest birakmak daha doğru bir usuldür. Çünkü bu suretle hâkim hâdisલlere kararını uydurabilecektir. Meselâ suça vekâlette müekkil, mağdura karșı kin besliyen bir kimseyi arar, bulur ve bu şahısta vekâleti memnunlukla kabul ederse, müekkilin cezasını böyle bir şahsı arayıp bulduğu için indirmek makul olmiyacaktır. Kanunun cezayı mecburî olarak indirmesi usulü azmettiricileri, kendinde suçu işlemek hususunda şahsî bir sebep bulunanları aramağa sevkeder:

İslenen suçtan mütevellit sebepler şahsî sebep olarak kabul edilemez. Vadedilen parayı almak için suçu işleyen fäldeki bu knzanç hursi șahsî sebep sayılamaz (36). Müekkilin dostlaọunu kazanmak için suç işlemis olan vekilde de şahsî sebep mevcut değildir (37). Aksi takdirde bütün hâdiselerde bir şahsî sebep bulmak mümkün olacaktir.

Şahsî sebep ile azmettirici tesirleri kabule mütemayỉ bir ruhî durumda bulunma halini karıştırmamak lâzımdır Azmettirme fii-

(34) Pozzolini n. 185.

(35) Nocito s. 335 - 338.

(36) Italyan Yargitay kararı Bruno m. 63.

(37) Nocito s. 337. 
line karşı failin ruhunda aż veya çok hazrrlanmış bir zeminin bulunuşu şahsî sebep mefhumuna dahil değildir. Üçüncü bir şahsi öldürmeğe, kendine âşık olan bir kimseyi onda kıskançIı buhranı tevlit temek suretile azmettiren kadın (38) failde bir şahsî sebebin bulunduğunu iddia edemez.

Faildeki şahsî sebepten dolayı azmettirenin ce:assinın indirilmesi için azmettirenin faildeki bu sebebe vâkzf olup olmamasinn ehem: miyeti yoktur. Ceza kanununun 45 inci maddesinden istihraç edilen prensiplere dayanarak tahfif sebebinin tatbiki için bu halin azmettirence bilinmiyen bir hal olması şartı ileri sürülemez. Çünkü bir keyfiyetin isnadı için lüzumlu, fakat muafiyet veya cezanı indirilmesi için aranmasına lüzum olmıyan bir şarttır.

Failde meveut şahsî sebepten dolayı ancak azmettirenin cezası indirilebilir. 64 üncü maddenin bu hususa dair olan hükmü munhasiran manevî - aslî ortağa tatbik olunur. Maddî - aslî ortaklar cezayı azaltrcr sebepten istifade edemezler (39).

II. FER'Í İSTTIRAK: Ferî faillerin tâyin edilmesi hususunda $i k \hat{i}$ sistem mevcuttur: Fer'î iştirak sayzlacak halleri hâkimin takdirine bərkmak, kanunda bu halleri ayr ayr göstermek. Bu iki usulün hangisinin tercih edilmesi lâzımdır? Fer'î iştirak hallerinin kanunda gösterilınesi usulünün hâkimin keyfî bir takdirini önlemek bakımından bir faidesi olduğu ileri sürülmektedir. Halbuki bu husus geniş bir tatbi ksahası bulan "kanunsuz suc ve ceza olmaz» kaidesi ile zaten önlenmiş bulunmaktadir. Kanunda fer'î iştirak hallerini saymak bilâkis bazı mahzurları müciptir. Kanunda sayma usulü ile muhtemel fer'î iştirak hallerine ancak sathî olarak dokunmak mümkündür, ve böyle bir usul çok karıssık, ihtilâflara meydan verici, eksik kalma tehlikesine maruz bir usuldür. Kanunî sayma usulüne yaplan en kuvvetli itiraz sudur: ortakların aslî iştirak halinde saylmaları onların fiilin maddî unsurların ișlemiş olmalarına istinat ettiriliyorsa Hafter'in işaret ettiği gibi suçun icrasına şu veya bu ortağın iştirak etmis olup olmast tesadüfe bağl bir keyfiyettir (40), suçun icrasında hiç bir hisse almamıs olan bir ortağın suçluluğu ve tevlit ettiği tehlike bakımından fer'î bir ortaktan ziyade aslî bir ortak gibi gözükmesi mümkündür. $O$ halde suç iradesinin kesafetine istinat etmek ve sucun icrasına katılmış olup olmamasına bakılmıyarak, bir kim-

(38) Manzini n. 475

(39) Italyan yargitay kararı, Bruno m. 63; Manzini n. 473 II.

(40) Logoz'dan naklen s. 94 . 
seyi suçun husulündeki umumî tesirine göre astî veya fer'î ortak saymak lâzımdır.

Kanunumuz fer'ì iştirak hallerini saymak usulünü tercih etmiştir ( $m$. 65 bent I, II, III). Bu sebeple herhangi bir faaliyetin fer'î iştirak sayllması mümkün değildir, kanunda gösterjlmemis olan bir iştirak faaliyetinden dolayı, bir kimsenin ortak sayılması imkânsızdir. Bu sebeple «iştirakin veçhe ve mahiyetinin kararda gösterilmesi lâzımdır” (41). Kanunun fer'î iştirak şekillerini sayma usulünü tercih etmiş ve bunları sayarken tahdidî bir usul kullanmış olduğuna bakarak aslî faillerle fer'î failler arasinda sadece mutavassit rolünü oynamıs olanların "kanunen» fer'î ortak sayılamıyacaklarnı saniyoruz. Bu sebeple "fer'an zimethalliğin fer'an zimethalliğin mümkün değildir (42), suçun ne suretle işleneceğine dair olan talimatı veya tedarik edilmiş olan vasitaları fer'î failden aslî faile sadece nakieden kimsenin durumu fer'î iştirak şekillerine dałìl değildir.

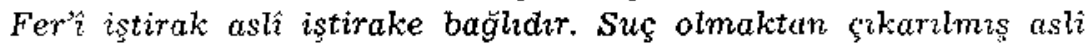
fiile katılmış olan fer'î ortaklar cezalandırılamazlar, bu sebeple unumî af veya zaman așımı ile kalkmış bir suçun fer'î failleri hakkında takibat icra edilemez, ceza verilemez.

Aslî fiilin suç teşkil etmesi şartı, unsurları meyanında "itiłyat şartı" bulunan suçlar bakımından ehemmiyet arzeder. Bu türlü suçlarda fer'î iştirakin cezalandırılması için topluluğu itiyat şartın meydana getiren fiillere katılmış olmak lâzımdır. İtiyadın teşekkül etmis sayliması için gereken faaliyetin tekrarından evvelki iştirak halleri fer'î iştirak sayılamaz, bu sebeple (müteaddit kimselerin her biri kanunî̀ hadden fazla ödünç para verme işlerine tevessül etmiş olan bir noter, suça iştirakten mahk $m$ edilemez) (43). Cünkü fazla faiz ile ödünç vermenin suç sayllması failde bu hususta hareketlerin taaddürüinden ileri gelen bir itiyadın husulüne bağglidir (44).

K.anunưn kabul etmiş olduğu fer'î iştirak șekilleri maddì ve manevî olmak üzere ikiye ayrılır. Fer'î iştirakin zarurí olup olmamasına göre de diğer bir tasnife tâbi tutulması mümküindür:

A. FER'I - MADD̂ी İSTIRAK: Fer'î mahiyette olmak üzere suça maddî bir faaliyet ile iştirak etmek halidir. Maddî - Fer'î failler, maddî - aslî faillerden şu suretle ayrllırlar. Maddî - aslî failler (suçu

(41) 1. C. D. 3. 7. 927 karar 3332

(42) Aksi mutalâa, Majno n. 3îo.

(43) Carraud III, n. 897.

(44) bk. ödünç para verme işleri kaßsunu m. 14. 
irtikập edenler, doğrudan doğruya beraber işliyenler) suçun kicrasınja iştirak,) 'ederler (m, 64 f. 1). Maddî - fer'î failler ise fer'î bir faaliyet ile sadece (suça iştirak)" etmişlerdir (m. 65).

Maddî - fer'̂̀ iştirak fiilin islenmesine yaryacak iş veya vastalar tedarik etmek. (m. 65 bent III) suç işlenmeden evvel veya işlendiği sırada muzaharet ve muavenetle icrastnı kolayiaştırmak (m. 65 bent III) sekilleri ile olưr:

a) IS VEYA VASITA TEDARİKI: Filin işlenmesine yaryyacak «iş» tedarik etmek kaydı meyhaz kanunda mevcut değildir. Kanunumuza bu ilâvenin "vasita" mefhumunu genişletmek maksadı ile konulduğunu sanıyoruz. Hirsızlık etmek niyetinde olduğunu bildiği bir kimseyji diğer bir şahsin evine hizmetçi olarak girmesini temin etmek hususu, fiilin işlenmesi için «iş» tedarki saylablir.

"Vasıta" tâbiri kanunda umumî bir tâbir olarak kullanılmuştır. Nenin vasıta sayılacă̆ını hâkim takdir eder. Bu sebeple "vasıta»" tâbirinin umumî mânası karşısında kanunumuza ilâve edilmiş olan (iફ̧») tâbiri lüzumsuzdur.

Vasita umumiyetle menkul eşyadır, silâh, bıçak, zehir vesaire gibi. Bir gayrımenkulün icabında suçun işlenmesirse yarnyacak bir vasita saylmasına mâni bir hüküm kanụnda mevcut değildir, kalp para imali için evini suçlulara veren kimse vasıta tedarik etmiş sayılmalıdır (45).

Vasıtanın suçu teşkil eden fiilin işlenmesinden evvel tedarik edilmi şolması làzımdır, bu husustaki hükmün geieceğe atfeder şekilde yazılmış olması yani «filin işlenmesine yarıyacak iş veya vasitalar tedariki" nden bahsedilmesi de bunu gösterir. Fiilin işlenmesi ile hem zaman olan vasita tedariki mađdî - aslî iştirak hallerine girebilir (46), fakat bu sahada kesin kaideler komak doğru değildir.

Fer'î failin mesuliyeti vasita tedarik etmiş olduğundandır. Bu sebeple tedarik edilmiş vasıta suçu işlemeğe elverişli değilse yahut fail bu vasitayı suçta kullanmamış ise fer'î ortağa ceza verilemez. Bu sebeple hursızlıkta kullanacağını bilerek başkasına merdivenini veren kimse eğer fail son dákikada bu merdiveni kullanmaksızın suçu işlemeyi münasip görmüş ise cezalandırılamaz. Suç mahalline gitmek için hrrsıza atını veren kimse de, gürültü olmaması için hirsızin yaya gitmeyi tercih etmesi halinde cezalandırlamiyacak$\operatorname{tir}(47)$.

(45) Aynt mahiyette Pozzolini n. 188 a.

(46) Ayni mahiyette Manzini n. 481; Pozzolini 188 a.

(47) Nocito s. $315,316$. 
b) MUZAHARET, MUAVENET: Aslî fail taratindan suç işlenmeden evvel veya işlendiği surada muzaharet ve muavenet ile icrastnı kolaşlaştırmak (m. 65. bent III) hali, vsarta tedarikinden müstakil bir haldir. Vasita tedarik eden kimsenin faaliyeti neticesi bakimindan "muavenet" mefhumuna dahil olabilir, fakat yardım ve muzaheret vasita tedariki mânasina gelmez.

Adam öldürme suçlusuna silâh tedarik etmiş olan kimse vasita tedariki suretile fer'î fail haline gelmiştir, halbukı suç işlendikten sonra bu suçlumun kaçmasını temin çarelerini sağlıyan yahut öldürülecek kimseyi pusuda uzun müddet bekliyebilmek için suçluya yiyecek götüren kimsenin faaliyeti (muzaheret, mliavenet" mefhumlarına dahil olur.

Suçun icrasını kolaylaştıran her türlü fiil muzahecet veya muavenet teskil edebilir.

Muzaheret ve muavenet suçtan evvel olabileceği gibi suç işlendiği surada da olabilir. Suç işlendiği suradaki muzaheret ve muavenetin fer'í iştirak hududunu aşmaması lâzımdır, aksi takdirde aslî bir iştirak şekli olan "doğrudan doğruya beraber işlemek" hali hâsll oiur.

Filin işlendiği esnada vukua gelen muavenet veya muzaheret şeklindeki fer'î faillik ile suçu doğrudan doğruya beraber işlemek hususundaki aslî faillik hallerinin ne şekilde tefrik edileceği ihtilâflıdır. Fransız müelliflerinden bazılar ile Fransiz yargıtayı teşebbüste izhar ve icra fiilleri tasnifinden bu sahada tatbik edilmek üzere bir kıstas elde etmeğe çalışışlardır. Bunlara göre icra fiilleri mahiyetinde olan hareketler fiili doğrudan doğruya beraber işlemeğe, ihzar fiilleri mahiyetinde olanlar da fer'î failliğe aittir.

$\mathrm{Bu}$ ölçünün tatbikî bir değeri yoktur. Çünkü jcra ve ihzar fiilleri arasında hukukan sarih bir hudut çizmek imkâni bulunamamiştır.

İcra ve ihzar fiilleri yerine icra edici, kolaylaştınc fiiller tasnifini ikame suretile belki daha vâzıh neticelere varılabilìr: Suçun işlenmesi sırasında suçun vukua gelmesi için zarurî olmıyan ve sadece işlenmesini kolaylaştıran hareketler suçun işlenmesi sırasında muzaheret ve muavenettir. Suçun işlenmesini kolaylaştırmaktan daha ileri giden ve suçun icrası mefhumuna dahil olan hareketler aslî iştirak hareketleridir. Bu ölçü fer'î faillerle aslî ortakiarın tefrikine yarar. Suçun icrasına herhangi bir şekilde iştirak eden kimse aslî faildir. Bu sebeple hırsızlık yapılan odanın kapısında gözcülük yapan kimsenin iştiraki aslî bir iştirak, suçun icrašna iştirak etmeksizin 
vaka mahallinde sadece hazir bulụnmak suretile suçlulara cesaret veren kimsenin durumu da fer'î iştiraktir.

Kanun vasita tedarikinin "suçtan evvel" husule gelmesini tasrih etmesine rağmen muzaheret ve muavenetin suģı teşkil eden fijl ile hem zaman olabileceğini kabul etmiştir.

Kanunumuzda "muzaheret ve muavenet» tâbirieri meyhaz kanununda (muzaheret veya muavenet) şeklinde kullanilmıstır.

Muzaheret (assistenza) failin şahsı ile ilgili, daimî veya hiç olmazsa uzunca bir müddet devam eden yahut tekerrür eden bir yardım şeklinde ortaya çıkar, suçun işlenmesini kolayısş̧ırmak için engelleri ortadan kaldırmak, tehlikeleri haber vermek, yahut icraya iştirak etmeksizin herhangi bir şekilde suçun işlenmesini kolaylaştırmak "muavenet» etmektir.

B. FER̂̉ - MANEVÎI ISTİRAK: Suç işlemeğe teşvik, suçu irtikâp kararın takviye, fiil işlendikten sonra muzaheret ve muavenette bulunacağın vâdetmek suçun ne suretle işleneçăine dair talimat vermek halleri manevî - fer'î istiraki teskil eder.

$\mathrm{Bu}$ türlü iștirak italyan hukukunda menșeini "consiglio" mefhumundan almaktadir. Bu mefhumun roma hukukutida daha etraflı bir mânaya geldiği ve roma ceza hukukunun tesiri ile geniş bir anlayışa meydan bırakmamak için meyhaz kanunun tanzimi sırasında mânevî - fer'î iştirakin tahdidi bir şekilde sayılması usulü tercih edilmiştir (48).

Manevî - aslî iştirak ile manevî - fer'î̀ iştirak bazı hallerde birbirlerine çok yaklaşan faaliyet şekilleri ile tezahür edebilir. Meselâ teşvik, suç kararm takviye halleri ile azmettirmenin tefriki bazan güçtür Tefrik için ölçü ortağın faaliyetinin suçun ilk ve müessir sebebi olup olmadiğtdir.

a) TEŞVIK: Tescik etmek, mevcut suç işleme kararinın tatbikına matuf faaliyetlerde bulunmaktır. Teşvik etmek (eccitare) tabirinde failde mevcut kararı icraya başlamağa sevketmek mânası saklıdır. Bu sebeple bahis mevzuu olan suça teşvik değil, suçluyu teşviktir.

Teșvik edilen kimsede sưç işleme kararının teşvikten evvel mevcudiyeti kabul edilince, bir kimsede suç işlemekte "şahsî bir sebep" olduğu neticesi de ortayà çkar. Fakat fer'î falilliğgir: zarurî bir vasf́ı olan bu hal hiẹ bir zaman fer'î-manevî faillik cezassnn indirilmesini

(48) Consiglio mefhumu ve tesitleri hakkında Nocito s. 347 - 351. 
mucip olamaz. Zaten aksi neticeye varmağa "şahsì sebep" ten mütevellit kanunî azaltıcı sebepleri aslî-manevî iştirake hasreden kanunun hükümieri de mânidir.

Munhasırän suçluyu, suç işlemeğe değil, suçun devamma da teşvi kmümkinindür, bu sebeple mütemadî ve müteselsil suçlarda temadî ve teselsülïn devamma teşvik hususu da ferrij-mattevî bir iștiraktir (49).

b) KARARI TAKVİYE: Failin vermiş olduğa suç işleme kararını kuvvetlendirmek, manevî bir iştirak hali teșkil eder. "Suçu irtikâp kararım takviye" (m. 65, bent 1) tâbirinin mânası budur, kanunda kullantlan suçu kirtikâp" kararı tâbiriniiz "suçu irtikâp edenler" (m. 65, bent 1) e munhasır bir mânaya alınması doğru değildir.

Ancak kararı kuvvetlendirici müessir bir faaliyet suç kararını takviye saylabilir. Bu sebeple cesaret verici sözler ve telkinlerde bulunulmaksızı başkasının kararını sadece tasdik etmek kararı takviye saynlmamalıdır. teyit takviye değildir.

Kararı takviye etmek, evvelce failin bu kararı vermiş olması ile mümkündür, aksi takdirde hâdisede azmettirmık bahis mevzuu olabi]ir

c) MUZAHARET, MUAVENET VA'Dİ: Suç işlendikten sonra muzaheret veya muavenette bulunacağın suçluya, suçtan evvel vadetmek manevî - fer'î biv iştiraktir. Suç ișlenmeden evvel yap̣lmış olan bu vait, suçu işleme iradesini kuvvetlendirir. Çünkü böyle bir vait tereddüt halinde bulunan bir suçlunun karşısındaki manevî mania1 ları kaldırır. Yakalanırsa ailesine bakulacağı, veya kaçmasının temin edileceği veya kendisine ceza evinde bakılacağı gibi vaitler suç iradesinin harekete inkılâbını temin eder.

Suçtan sonraya ait bir muzaheret veya muavenetin suça iştirak sayilmasının sebebi, bu suretle suçlunun iradesinin kuvvetlendirilmiș olmasından ileri gelir, binaenaleyh vaadin suçtan sonra tutulmamıs olması, yani vadedilmiş olan yardımm, muavenetin yerine getirilmemiş olması, vadedenin ortak sayılmasına mâni değildir, çünkü suçun işlenmesi ile vait tesirini göstermiştir. Vait yerine getirilmemiş ise, bir çok hallerde hâkime takdir hadleri arasında hafif ceza tâyini dahi tavsiye edilemez, samimî bir nedamet bahis mevzuu

(49) Bu hususta Manzini n. 488 .V. 
değilse, vadini tutmamak, suçlu psikolojisi bakımmdan, kötülüğün bir delilidir (50).

Vaidin suçun tekemmüiünden evvel yapılmış olması lâzımdir. $\mathrm{Bu}$ sebeple temadi, teselsül veya teşebbüs sona errıeden evvel yaprlan vait, suçtan evvel yapllmiş saylmalıdır.

Suç eşyasını saklıyacağını veya satın alacağını yahut suçluyu sakliyacâğını suçtan évvel vadetmiş olan kimse 296. 512 inci maddelere göre değil fer'î iştirak hükünlerine göre cezalandırılır.

§) TALIMAT VERMEK: Suçun ne suretle işlenebileceğini bildirmek, "talimat vermek" tir. Talimat vermek hali, vasita tedarilki ile ayn bentte (m. 65 bent II) gösterilmiş ve meyhaz kanunun gerekçesinde bu iki halin biribirine çok yakm olduğu bilđirilmiş olmasina rağmen (51) talimat vermenin manevi, vasita tedarikinin ise maddî̀ bir işstirak hali olduğu aşikârdır:

Talimatın suç işlenmesinden evvel verilmiş olması lâzımdır, suç ile hem zaman olan talimat vermek aslî iștirake girer (52).

Talimat vermek bir çok hâdiselerde teşvik ve suç kararmı takviye hallerile karışmı olabilir. Talimat, diğerlerinden suç işleme iradesinden ziyade akla hitap etmesi ile aymlir. Teşvik ve kararı takviyede suç iradesini kuvvetlendirmek, şiddetlendirmek bahis mevzuu olmasına mukabil talimat vermede suç kararının muşahhas hâdise haline inkilâp ettirilmesi bahis mevzuudur.

Talimat verilmesi hususî bir şekle bağlı değildir.

Talimatin, suçun işlenmesinde maddî bir tesir icra ețmiş olması talimat verenin mesuliyeti için şarttır. Nasıl vasıta tedarikinde, tedarik edilen vasıtanın kullanılmamış olması, ortağın cezalandırılmasina mâni ise, verilen talimatın suçun işlenmesinde faide temin etmemiş olması da öylece, ortağın mesuliyetinde maddî unsuru ortadan kaldırır.

C. FER' Î ISTTIRAKTE ZARURET: İster maddî, ister manevî mahiyette olsun fer'î iştirak fiillerinin bazı hâdiselerde suçun husule gelmesinin zarurî bir şartı olması mümkündür. Kanun zarurî olan ile zarurî olmıyan fer'̂̀ iştiraki cẹa bakımından farkli hükümlere tâbi tutmustur:

a) ZARUR̂ि OLMIYAN FER' İ I̧TIRAK: Fer'î iştirakte ortağa

(50) Manzini n. 480 II.

(51) Pozzolini n. $186 \mathrm{C}$.

(52) Manzini n. 481; Florian s. 44, 45

Hukuk Fakültesi Mecmuası 
verilecek ceza, aslî failin işlediği suçun kanunda yazılı̀ cezasinin muayyen bir miktarda indirme (53) yapilarak tâyin olunur.

Aslî faile verilecek muşahhas cezanın fer'î failierin cezasina tesiri yoktur. Fer'î faillere tatbik edilecek müeyyide, temel - ceza, suçun kanunda yazll cezasıdır (54): Bu sebeple fer'i iştirak aslî iştirakin cezasını azaltan bir sebep değil, müstakillen cezayı müstelzim bir faaliyet şeklidir ve müeyyidesi ayrıca gösterilmiştir (m. 64). Aslî faillerle, fer'î faillerin davalarmın irtibat dolayısı ile ekseriya birlikte görülmesi esasa değil, usule ait bir meseledir.

Yine aynı sebepledir ki, aslî failin taayyün etmemiș olması, fer'î failin cezalandırılmasına mâni değildirr.

b) ZARURÎ OLANR FER'Î İSTIRAK: Fer'î istirak fiillerinden birini işliyenin suça iştiraki inzimam etmeksizin suçun işlenmesi mümkün olamıyacağı sabit olan hallerde iştirak zarurî iștíraktr.

İstirakin zarurî olup olmadığın müşahhas olarak değil, mücerret olarak ele aimak lâzımdir. Müșahhas hâdiselerde suçun ișlenmesine bilfiil müdahale etmiş her hareket, neticeyi tevlit etmek baklmindan, zaruridir, çünkü suç bütün iştirak f́illerinin muhassałasıdrr, bu sebeple her fer'î failin, zarurî - fer'î fail sayılriası lâzımgelecektir. Ancak mücerret bir tarzda düşünüldügüu takdirde elde edilecek nispi bir zaruret ile zarurî fer'î failleri tâyin etmek mümkündür. $\mathrm{Bu}$ sebeple meyhaz kanunun gerekçesinde denildiği ve bir cok müelliflerce tekrar edildiği gibi (55) suçluya silâh tedarik eden zarurî fer'î fail değildix, çünkü katil diğer bir silâh tedarik edebilir ve hatta hiç silâh kullanmaksızın suçu işliyebilirdi, fakat zehirle öldürmek suçunda zehiri hazırlıyan eczacı hemen daima zarurî - fer'î faildir.

Zaruret her hüdisede başka türlü gözükebilir, bu sebeple hangi iştirakin zarurî̀ olduğu umumî̀ olarak tâyin edilemez, en ehemmiyetsi zgibi görünen bir hareket zarurî bir iştirak halini teşkil edebilir, el yazısı ile tanzim edilmiş bir vasiyetnamenin yakılmasında bir tek kibrit böyle bir iştirakin mevzuu olabileceltir (56).

(53) Kanunun tâyin ettiği indirme ölüm cezası ve müsebbed ağır hapis yerine on seneden aşağı olmamak üzere ağır hapis, diğer hallerde suçun müstelzim olduğu cezanın yarısıdır. Maddede müebbeden amme hizmetlerinden memnuiyet hakkında bir kayıt mevect olmadı̆̆ından bu cezanın inditmeye tâbi tutulp tutulamryacağı kati olarak bilinememektedir, Majno indirme yapılamiyacağ: fikrindedir, Majno n, 352.

(54) Aynı mahiyette, İtalyan yargitay karar1 Bruno m. 64.

(55) Ezcümle Florian s. 45; Manzini n. 349 not 1; Pozzolini n. 189.

(56) Nocito s. 315 . 
Bir iştirakin zarurî olabilmesi için, aslî fỉilin işlendiği sırada yapılması şart değildir, suçun işlenmesinden evvelki safhalarda da bir iştirak zarurî bir iştirak olabilir. Bu sebeple zarurî - fer'î iştirak ile zarurî olmıyan fer' iştirak hallerinin birbirinden tefriki kronolojik kistaslara göre yaprlamaz (57).

Zarurî - fer'̂̀ faillik ismi verilen iştirak şekli fer'î failliğin ne bir nevi ve ne de bir şiddet sebebidir Zarurî - fer'̂̂ faillerin cezanm tahfifinden istifade edemiyeceklerini bildiren hüküm ( $m .65$ son $f$ ) ile kanun bazı fer'î iştirak faaliyetini aslî iştirak seviyesine çıarmiş değil, fer'̣̂ - zarurî iştirakin aslî iştirakten başka bir şey olmadığını göstermek istemiştir. Cünkü fiile inzimam etmediği takdirde suçun işlenmesine imkân olmıyan bir hareket fer'î bir iştirak sayılamaz. Bu sebeple meselâ, teşvik veya karar takviye şeklinde bir fer'̂े iştirak faaliyeti haddi zatında azmettirmekten başka bir şey değildir.

$\mathrm{Bu}$ anlayış bilhassa, failin suçu işlemekte "şahsî sebeb" i mevcut olduğu hâdiselerde ehemmiyet arzeder. Aslî iştirakte azmettirenin cezası failde mevcut şahsî sebe pdolayısiyle indirilir (m. 64 f. 2), buna rağmen azmettiren aslî bir iştirakte ortaktır. Fer'î - zarurî fail ise aslî iştirak cezasına çarpılır, halbuki kendisi fer'î bir faildir. Bu tezad Manzini'nin de işaret ettiği gibi (58) zahiridir. Çünkü fer'î manevî . zarurî̀ bir fail hadđdı zatında azmettirenden başka bir kimse olamıyacăğı göre, bu .kimse hakkında faildeki sahsî sebepten mütevellit tahfif sebebini tatbik etmemek için sebep yoktur.

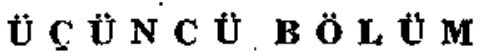 \\ CEZAYA MỨESSIR SEBEPLERIN ORTAKLARA SIRAEYTí}

İştirak hạlinde işlenmiş suçlarda ceza üzerine müessir sebeplerin ortakların mesuliyetine tesir edip etmiyeceğinin tâyini lâzımdır.

Suç ortaklığında "cezaya müessir sebeplerin ortaklara sirayeti» önemli bir konudur. Bu meselenin hallinde cezaya muiessir sebeplerin tesir ve menşe bakımından tefriki lâzım gelmiektedir:

Ceza üzerine müessir sebeplerin bu tesirlerini cezayi kaldırmak, indirmek veya arttırmak şeklinde gösterirler. Menşeleri bakımından da ortaklardan birinin şahsindan veya işlenmiş olan suçun maddî bütünlügünden ileri gelebilir. Ortaklardan birinin şahsından ileri

(57) Italyan yargitay karar1, Bruno m. 64.

(58) Manzini n. 475 III. 


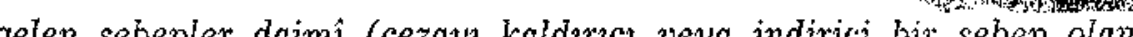
ci bir sebep olan kücüklü khali gibi) yahut arizi (cezayn indirici bir sebep olan tahrik gibi) bir sebep olabilir. Bu sebeplerin kanuna veya takdire dayanmasina göre de bir tefrik yapmak mümkündür.

O halde ortaklardan biri hakkında mevcut saylan ve cezayi kaldıran, indiren veya arttıran şahsî veya filití; daimî̀ veya ăızi; kanunî veya takdirî; sebeplerin diğer ortaklara sirayet edì etmiyeceğinì bilinmesi lâzım gelmektedir.

Kanun cezay kaldran, indiren sebeplerin sirayeti hakkinda

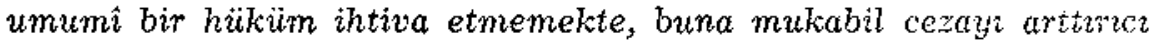
sebeplerin sirayeti meselesini tanzim etmektedir (m. 66,67$)$ :

I. CEZAYI KALDIRAN INDİREN SEBEPLEK: Cezayı kaldırran veya indiren sebepler hakkanda kanumun umumî bir hüküm ihtiva etmemesinden bu sebeplerin kendisinde mevcut olan ortaktan gayrisina tesir etmiyeceği neticesi çlkar, o halde kaide cezayı kaldiran veya indiren sebeplerin sahsiliğidir.

Ceza mesuliyeti olmıyan bir kimsenin (küçük, akıl malûlü gibi) işlemiş olduğu suçta ortaklarm faildeki bu şahsî - daimi cezasızlık sebebinden istifacie edemiyecekleri aşikârdır, bu gibi hallerde ortaklık, esasen suçun faili sayllırlar (1).

İştirak halinde işlenilmiş bir suçta ortaklardan birinin tahtik edilmiş olması diğerlerinin cezasına tesit edemez: cezayı azaltıcı şahsî - arızi bir sebep olan tahrik ancak tahrik edilenin cezasım indiren bir sebeptir. Eğer bütün ortaklarm tahrik edilmiş oldukları kabul edilirse hepsinin cezası indirilir, fakat bu hal cezayı indiren sebebin sirayeti değil, bütün ortaklar hakkında ayrs ayr kabulüdür Bu gerekçeye binaen abir suça iştrak edenlerden biri hakkında tahriki kabul, diğerleri hakkında reddeden hükǜm mütenakız bir hüküm sayılamaz” (2) ve aslî fail hakkmnda tahrikin kabulü, diğgerlerinin cezasinm indirilmesini icap ettirmez (3).

Başkasının meşru müdafaasına (m. 49) iştirak eden ortak cezasızlık sebebinden sirayet yolu ile değil, müstakilten istifade eder. Aşırı müdafaa (m. 50) hali de aynı kaideye tâbidir. Kanun hükmünü selâhiyeți merciin emrini yerine getirme (m. 49 bent 1) halinde des filli isliyenin ortağına ceza verilemez. Bu sebeple kapalı kapıyı baciz memurunun isteği ile kıran işçi mesken masuniyetini ihiâl suçunu

(1) Italyan yargitay kararı Bruno m. 63; Majno n. 361.

(2) İtalyan yargitay karari, Bruno m. 63; Majno n. 361.

(3) Ayn mahiyette Italyan yargıtay kararı Suman m. 63 III. 
i̦slemiș olmaz, haciz memuruna böyle bir fiilden dolayı ceza verilmesine mâni olan sebep iş̧̧iye de ceza verilmesine nânidir (4).

Iftiradan dönme (m. 285 f. 2) çalman şeyin geri verilmesi (m. 523) halleri diğer ortaklara sirayet etmez, iftiradan dönmek, çalınanı geri vermek, zararı tazmin etmek şahsî nedamet duygularina dayandığından sirayet etmeme bu cihetten de doğrudur (5).

Yeni doğmuş çocuğun öldürülmesinde şeref korımak kaygusu (m. 453) tamamile șahsî bir haldir.

Calınan malın veya zararm hafif veya pek hafif oluşu (m. 522) bütün ortaklarn cezasina tesir eder, fakat bu hal bir "sirayet" saylamaz. Çünkï bu hâdisede hexhangi bir halin bir ortaktan diğgerine geçişi bahis mevzuu değildir (6).

Aile hirsızlığnda takibata ve cezaya mâni sebẹ (m. 524 f. 1) ve cezayı indiren sebep (m. 524 f. 2), kendinde bu sebep bulunan ortaktan gayrisina tesir etmez (7).

Buraya kadar verilen izahattan cezayı kaldran, indiren sebsplerin sirayeti hakkındaki umumî kaideyi istihraç etmek mümkindür: cezayı kaldran ve indîen sebeplerin ortaklara sirayet etmemeși kaidedir. Ortakların cezasm indirmek veya kaldırmak için sebepisrin sirayetini aramağa lüzum yoktur, fịlin mahiyetine göre ortakların her biri hakkunda cezayı indiren bir vasfin meveu tolup olmadığına bakmak lâzımdir.

Bazı müellifler cezayı arttıran sebeplerde olduğu gibi cezayı kaldıran ve indiren sebeplerde de şahsî ve fiilî olmak üzere bir tefrikin yapilmasını ve birincilerin sirayet edemiyeceğini, ikincilerin ise sirayet etmesi lâzım geleceğini ileri sürmektedirler, bu müelliflere göre küçüklük, zina halinde yakalama, tahrik gibi haller birinci grupa, hırsızlikta çalınan şeyin, șahsî hürriyetten máhrumiyet

(4) Nocito s. 368 .

(5) Aksi miitalâa Nocito s. 368; «iade ve tazminin cezay indirmesi hususu bir zarar mevcut olması esasına dayanır. Ortakların yalnız biri tarafından yapılmış olsa bile bunun diğerlerine sirayet etmemesini kabule imkân yoktur *Mühastran bu mesele hakkında verilmiş olmamakia beraber aşağłaki karar, Yargıtayın temayülü̈nü gösterebilir»: Ceza kanununun 523 ünxü maddesinde, suç ișliyen kimsenin zararı tazmin etmesi ciheti mevzuubahis olup reşit bulunduğu halde haberi olmaksızın ve arzusu hilâfına bir başkası tarafından zararın ödenmiş bulunmasına göre, suçlunun mezkôr maddede yazılı tenzilâttan istifade ettirilmesine kanunî imkân yoktur. C. Gk. 21. 9.936 esas 4 - 100 karar 97».

(6) Manzini n. 490.

(7) Ayn1 mahiyette Nocito, s. 367, 368; Florian s. 52. 
ve kaçrma suçlarında hürriyetin iadesi hususu ikinci grupa dahil olmalhdir.

Bu fikrin nazarî bir değeri olabilirșe de kanunumuzun sistemine uymadığl aşikârdır (8).

II. CEZAYI ARTTIRAN SEBEPLER: Cezayı arttıran sebeplerin ortaklara sirayet edip etmiyeceği hususunda kanunda sarih hükümler mevcuttur ( $m .66,67)$. Bu hükümlerin tetkikinden cezayı arttırıcı sebeplerin sirayetinin kaide olarak kabul edildiği neticesi çlkarılamaz. Kanun cezayı arttıran sebeplerin ancak bazı şartlar mevcut ise sirayet edeceğini kabul ettiğine göre sirayet hali istisnadır. Bu sebeple iştirakin sabit olması cezayı arttıran sebeplerin sirayeti için kâfi değildir.

Cezayı arttrran sebepler şahsî ve fiillî olmak üzere jkiye ayrılırlar. Birincilerin sirayeti 66 unc1 maddede, ikincilerin sirayeti. 67 inci maddede gösterilmiştir.

A. CEZAYI ARTTICI ŞAHSI SEBEPLER: Cezayı arttıran șahsî sebepler failin kötülük derecesini gösteren (Mülserrirlik gibi) fail ile mağdur arasındaki rabıta dolayısiyle suçu suçu daha vahim addettiren (adam öldürmede evlât stfatı, hırsızlıkta hizmteçilik sıfatı gibi) sebeplerdir.

Cezayı arttrrie sebeplerin sirayetinde bahis mevzuu olan $k a$ nun $\hat{\imath}$ - șhsî siddet sebepleridir. Bu sebeple takdire dayanan cezay! arttırıcl sebeplerin sirayeti bahis mevzuu değildir.

Suç unstıru olan şahsî vasıflar, şiddet sebebi olmadiklarmndan sirayet etmeleri de düşünülemez, memuriyet nüjuzunu suiistimal suçunda memurluk sıfatı gibi. Böyle suçlara katılmak sadece ortakIığı meydana getirir.

Sahsî̀ sebeplerin sirayeti bütïn ortaklara şamildir. Aslî ve fer'î iştirakin her șekli bu kaideye tâbidir. $66 \mathrm{mct}$ maddedeki suçu "uberaberce ișliyenler "tâbiri yalnzz suçu” doğmudan dơ̆ruya beraber işliyenter" e değil ayn zaman "fiili irtikâp edenler" e de şamildir. Aynı maddede kullanılan suçun "icrasın kolaylaştırmağa yardım edenler» tâbiri de fer'î iştirakin bütün şekillerini ihtiva eder. $O$ halde suçtaki hisseleri ne olursa olsun, herhangi bir ortakta mevcut cezayı arttıran sahsî bir sebep diğerlerine sirayet edebj]ecektir. $O$ halde șiddet sebebinin doğrudan doğruya beraber işliyenlerden, birinden diğerine irtikâp edenlerden diğer ortaklara, hatt:i azmettirenden

(8) Kanunumuzun sistemi ve bu fikrin tenkidi hakkmda Pozzolini n. 193. 
icra edene, icra edenden diğer ortaklara, aslî faillerden fer'î faillere ve fer' şiddet sebebinin kendisine sirayet ettiği kimseyi işaret etmek için kullanlan "fail" kelimesi "ortak" mânasmadır.

Şahsî şiddet sebeplerinin sirayeti hakkında meyhaz kanun (m. 65) iki şart aramaktadır: şiddet sebebini teşkil eden hale ortağın suça iştirak anında vâkıf olması (vukưf şartı) ve bu halin suçun işlenmesini kolaylaştıran bir hal olması (kolaylaştırma şartı).

Kanunumuz meyhazdan ayrılmıs ve yalnız vukuf şartını kabul etmiştir. Bu suretle diğer ફ̧artı almamakla kanununuz haddi zatında bir istisna teşkil eden sirayet hâdisesini, genişletmiş bulunmaktadır. Şahsî olan sebeplerin sirayeti kanunun istinat ettiği umumî mesuliyet prensiplerine uymadığı ve prensiplere göre her şahsın kendi fiil ve sıfatından mesul tutulması lâzım geldiğine, ancak bazı şartlar mevcut ise istisnai olarak sirayetin kabulü mümkün olduğu düşünülecek olursa (kolaylaştırma şarti) nın alınmaması istisnaî izah edecek esaslardan birinin terkedilmesi gibi doğru olmiyan bir netice vermektedir.

Siyasî hürriyet aleyhine işlenen cürümlerde (m. $1774 \mathrm{f}, 2$ ), bazı devlet eşyasıriın ortadan kaldırılması suçlarında (m. 275. f. 2) memurluk sıfatı ve ırza geçme baştan çıkarma, iffete taarruz suçlarında veli, vasi vesaire gibi sifatlar (m. 417), hirsizlikia (m. 491 bent 3 ) emniyeti suiistimalde (m. 510) emniyete muhalefetten ileri gelen sebeplerin cezayı arttırıci sebep olmaları, suçun işlenmesinde bu hallerin hususî bir kolayluk temin etmiş olmalraindandrr. Bu sebeple bunlairn ortaklara teşmili ancak bu kolaylığın mevcut olduğu ahvalde hakl olabilir.

Kolaylaştırma şartının aranmas haksız sayılabilecek bazı sirayet hallerine de sebebiyet verebilir: ortaklardan birinin mükerrir olması halinde bu şahsî - arizi (geçici) sebebin diğerlerine sarî olması, birlikte işlediklèri suçta hiç bir alâkası bulunmıan bir keyfiyet olduğundan diğerlerine sirayeti de doğru değildir.

Adam öldürme suçunda taammüdün sirayet edip etmiyeciğ ihtilâflı bir mesele halinde kalmaktadrr. Meyhaz kanunu tatbik etmiş olan italyan yargıtayı bir çok vakalarda sirayeti reddettiği halde bilâhire kabul etmiștir (9), (10) Suçlunun iradesine taallûk

(9) İtalyan yargttay içtihadının değişmeleri hakkında Altavilla, n. 108. Taammüdün sirayeti hakkındaki içtihadı italyan yargıtayı șu fikre istinat ettiriyordu: «aslî fail bakmmindan suçun sübjektif unsuru olan taammüd, evvelce teșekkül etmiş olan suç taşavvurunu bilen fer'î fail için suçun obpektif un- 
eden onir kastinı arttran bu sebeple tamamiyle sübjektif mahiyette olan taammüdün ortaklara sirayet etmemesi daha muvfiktir (11).

Cezayı arttıran şahsî sebeplerin sirayetinde ikinci şart "ڤnukuf şartın dir. Bu şart sirayetin manevî unsurunu teskil eder. 60 me maddedeki bu hüküm kast hakkındaki umumi kaidenin (m. 45) iususî bir tatbik şeklinden başka bir şey değildir (12)

Kanun cezayı arttıran şahsî sebeplerin sirayetini kabul etriniş olmakla beraber, bu sirayete maruz kalan ortaklar (13) haklinda cezayı tahfif etmek imkânını hâkime vermek suretile sirayet hükmünün sertliğini gidermek istemiştir. Cezanm indirilmesi mecburì değildir, ortak için bu husus bir hak teşkil etmez, fakat tahfif talebinde bulummak hakkıdır (14), talebin vukuu ve reddi halinde hïkümde gerekçeli bir kaydın bulunması lâzımdır.

Kanunun aksini kabul etmediği hallerde cezanin indirilmesi daima mümkündür.

Fłâkim cezanın indirilmesine ait olan selâhiyetini hâdiselerin hususiyetine göre kullanir.

Kanunumuzun 66 inel maddesinin son cümlesinin yazzlıs sekli ölü ve müebbed ağır hapiste mecburî diğer halierde ihtiyarı bir indirmenin mümkün olduğu şeklinde ise de, bu hükrnün bütün hallerde hâkim için cezayı indirmek hususunda ihtiyarî bir hal olduğunu ve maddenin yazılışndaki sakatlığm bir gramer hat:dsndan ibaret bulanduğunu kabul etmek lâzımdır.

suruđur: Altevilla çok ender tesadü fedilen suçun işlenmesini taammüdün kolaylaștırması hali müstesna taammüdün sirayetinin doğru olmıyacağını, taammüdün objektif bir unsur haline inkilâbının mümkün olmadığını, objek bakımdan suçun daima aynı kaldığını ileri sürmektedir, n. 108.

(10) Italyan yargitay kararı Bruno m. 64: "taammüdün fer'î fail hakkında kabul edilip aslî fail hakkında kabul edilmemesi mümkündür ". İtalyan yargtay kararı Suman m. 65. III: «taammü, münhasıran sübjektif bir sebep olduğundan, suçiulardan biri hakkında taammüdü kabul, diğgerlerł hakkında reddetmek mümkündür». Ayn mahiyette Italyan yargıtay kararı Florina s. 55 .

(11) Aynı mahiyette Manzini s. 490 II. (Manzini canavarca his, menfaat tefini cezadan kurtulmak gayesi içinde bu fikri dremeyan eder); Majno n. 362; Nocito (s. 369) taammüden işienmiş olan suçun ancak czun bir düzünme ve hazırlama neticesinde bulunmuş vasıtalarla ișlendiğ takdirde, bu halin suçun işlenmesini kolaylaştıracağından ortaklara sirayetiri kabul eder.,

(12) Ауп mahiyette Majno n. 364.

(13) Fessina m. 65: «kanun, șahsî sebep veya hali doğrudan doğruya kendisinde bułunmiyan timsenin cezasını indirmek ihtiyarını hâkime tanıtmiștır».

(14) Manzini n. 490 II. 
B. CEZAYI ARTTIRICI FIILI SEBEPLER: Cezayı arttran fiilî sebepler, suça bağlı veya suçta meknuz sebeplerdir.

Ortaklara sirayet edece kolan fiilî sebepler, sadece fiilî şiddet sebepleri olabileceği gibi suçun vasfmı tebdil edici yani başka bir suçun unsurunu teşkil edici sebepler de olabilir. Kanun fiilî sebeplerin sirayetinden bahsederken (m. 67) suçun vasfın değiştirici sebepleri bilhassa işaret etmiştir. Bu sebeple yağma suçuna (m. b95) iştirak edenler, mukavemet karşısında kalırlar ve yağmayı tahakkuk ettirme kiçin adam öldürürlerse yağma suçunu adam öldürme suçuna (m. 450 bent 7 ) inkilâp ettiren sebep, bütün ortaklara sirayet eder.

Fiilî̀ sebeplerin birçoğu suçta kullanlan vasıtay ilgilendirir, kıyafet değistirmek (m. 493 bent 3,497 ) hiyle (m. 179) cebir istimali (175, 495) silchh (497) vesaire gibi. Diğer bazı siddet sebepleri de suçun işlenme zamanından, suç mahallinden, suç mevizuundan, suçun mağdurundan ileri gelir, gece vakti, felâket anlarında işlenen suçlar (m. 492 bent 3,497 ), umumun menfaatine tahsis edilmiş eşyalar üzerinde işlenen suçlar, nakil vasıtalar içinde işlenen suçiar (m. 492 bent 6). mukavemetten aciz olanlara aleyhine islenen suçlar (m. 414 f. 2) da olduğu gibi.

Bazi şiddet sebeplerinde hem şahsî hem fiilî bir vasif görülebilìr. Usul veya furuğdan biri aleyhine fena muamelelerde bulunmak halinde olduğu gibi ( $m .478 \mathrm{f}$. 2). Böyle hallerde fiilî̀ unsur, daha hâkim görülmektedir (15).

Şahsî sebeplerde olduğu gibi, fiilî sebeplerde de bütün ortaklara suçtaki hisseleri ne olursa olsun sirayet eder (16) 67 inci maddedeki "şerikler" kaydı bunu sarahaten göstermektedir. Fiilî sebeplerin bütün ortaklara sirayeti makuldür. Cünkü bu sebepler suçta vahdet teşkil eden vakialara istinat eder.

Fiilî sebeplerin sirayeti içinde vukuf şartı aranır. Suç işlendiği zaman da ișddet sebeplerine vâkıf olan ortaklar bu şiddet sebebi teşkil eden hale ruza göstermiş, onu istemiş demektir. Aksi takdirde ortaklıktan çekilmeleri lâzım gelirdi.

Vukuf şartı fiilen tahakkuk etmelidir. Suça iștirak anında tah mini mümkün șiddet sebeplerinin tahmin imkânına müsteniden or-

(15) Manzini n. 490.

(16) Bu sebeple kilit kırmak keyfiyetinin hirsılığtn cezasını arttıran diğer sebepier glbi bu keyfiyeti bilen ve istiyen gözcüye de şamil olacağuna ve sirayet için ortağin suçu icra eden bir kimse olmasina ihtiyaç bulunmadigona karar verilmiştir, İtalyan yargıtay kararı $\mathrm{Bruno} \mathrm{m} .63$. 
taklara sirayetine karar verilemez. Tahmini mümkün sebeplerin ortaklara sirayeti kaidesi vukuf şartının fijlen mevcut olmasım istiyen kanunumuz sistemine aykırıdır (17).

Tahmin edilebilme nazariyesine kadar gitmemek ve aynı zamanda vukuf şartının fïlen mevcut olmasını istemek suretile aşirı neticelere varmamak için, fiilen mevcut oima ölçïşïnün makul şekilde kullanılması lâzımdır. Bu sebeple ortağ meskûn bir eve giren ve hrrsizlık için kilit kıran kimsenin bu fiili şidde: sebebini istemiș olduğu aşikârdır, çünkü meskûn bir evde bilhạssa kıymetli eşyaların meydanda bırakılamıyacağ tabiidir (18).

Kanunumuza göre vukuf şartının "fiil işlendiği zamanáa" (m. 67) tahakkuku lâzımdır. Meyhaz kanun ise ortağın suça iștirak ettiği zamanda fiilî sebebe vâkıf olmsal lâzım geldiğini bildirmektedir. Kanunumuz cezayı arttırıcı şahsî sebeplerin sirayetinde vukuf şartın ortaklar suca "iştirak eyledikleri zamanda" (m. 66) aramasına mukabil cezayı arttrrıcı tiilî sebeplerde "fiil işlendiği zaman" (m. 67) nı esas tutması sebebini izah etmek pek müşküldür. Vukuf şartı şiddet sebebi teşkil eden vakıa istenmediŏi takdirde ortaklıktan çıkabilmek imkânına istinat ettiğine göre, ekseriya manevî iştirak şekillerinde bu imkân ancak iştirak anında mümkün olabileceğinden 67 inci maddenin meyhazdan ayrılmasinda hiç bir isabet mülâhaza edilemez.

Ortakiardan birinin "aşı hareket" etmesi halinde diğerlerinin, anlaşma hududun uaşan hareketlerden mesul tutulup tutulamiyacaklarının tetkiki lâzımdır: mesuliyetin hududunu anlaşma tahdit ettiğine göre ortaklardan birinin birleşmis iradeler hilâfina ve digerlerince bilinmiyen veya istenmiyen aşır hareketi sirayet edemez, bu sebeple müstereken intikam almak için bir kimseyi öldürmeğge karar vermiş olanlardan birinin suçun işlenmesinden sonra diğerlerinin arzusu hilâfına veya haberleri olmaksızın ölenin üzerindeki eşyayı da alması halinde, anlaşmayı aşan bir hareket, onu isliyene münhasir kalır.

Aşırı hareket ile "bir vasıta yerı̌ce diğerinin ikamesi» halini karıstimmamak lâzımdır. Diğerinin yerine ikame edilen vasıtanın suçIuluğu ve müessi rolma derecesi anlaşma hududu dahilinde kallyorsa, vasıtanm değiștirilmiş olmasının ehemmiyeti olamaz.. Bu sebeple

117) Meyhaz kanun hazırlanırken tahmin imkânının gayrı kâfi olduğu ve böyle tir arasturmanin gụ̧̈ ve keyfî olacağı bu sebeple fiilen vâkıf olmanin Jâzim geldiặ hususưrida müzakere cereyan etmiş ve bu şart böylece kabul eđilmiştir, bu husustaki müzakere zabitları jçin Nocito s. 377 .

(18) Nocito s. $376-380$. 
eğer suçu vekâlet tarzında işlenilen kendiliğinden hak almada müekkil, suçun şahıslara karşı şiddet kullamılarak (m. 308 f. 2) işlenmesini istemiş ise mesuliyeti, vekilin bu şiddeti istimal şekli ne olursa olsun ayn kalır. Fakat suçun eşya üzerinde cebir istimali (m. $308 \mathrm{f}$. 1) nden öteye gitmesini istememiş olduğu takdirde, müekkil vekilin şahısłara karşı şiddet kullanmasından mesul tutulamaz.

Faruk EREM 